\title{
Long term measurements of sulfur dioxide, nitrogen dioxide, ammonia, nitric acid and ozone in Africa using passive samplers
}

\author{
M. Adon ${ }^{1,2}$, C. Galy-Lacaux ${ }^{1}$, V. Yoboué ${ }^{2}$, C. Delon ${ }^{1}$, J. P. Lacaux ${ }^{1}$, P. Castera ${ }^{1}$, E. Gardrat ${ }^{1}$, J. Pienaar ${ }^{3}$, \\ H. Al Ourabi ${ }^{4}$, D. Laouali ${ }^{5}$, B. Diop ${ }^{6}$, L. Sigha-Nkamdjou ${ }^{7}$, A. Akpo ${ }^{8}$, J. P. Tathy ${ }^{9}$, F. Lavenu ${ }^{10}$, and E. Mougin ${ }^{11}$ \\ ${ }^{1}$ Laboratoire d'Aérologie, UMR 5560, Université Paul-Sabatier (UPS) and CNRS, Toulouse, France \\ ${ }^{2}$ Laboratoire de Physique de l'Atmosphère, Université de Cocody, Abidjan, Cote d'Ivoire \\ ${ }^{3}$ School of Chemistry, North-West University, Potchefstroom 2520, South Africa \\ ${ }^{4}$ Département de Physique, Université d'Alep, Alep, Syria \\ ${ }^{5}$ Département de Physique, Université Abdou Moumouni, Faculté des Sciences, Niamey, Niger \\ ${ }^{6}$ Département de Physique, Université de Bamako, Bamako, Mali \\ ${ }^{7}$ Centre de Recherches Hydrologiques, Yaoundé, Cameroon \\ ${ }^{8}$ Département de physique, Université Abomey Calavi, Cotonou, Benin \\ ${ }^{9}$ Direction Générale de la Recherche Scientifique et Technologique, Brazzaville, Congo \\ ${ }^{10}$ Centre d'études spatiales de la biosphère, UMR 5126, Toulouse, France \\ ${ }^{11}$ Laboratoire des Mécanismes et Transferts en Géologie, UMR 5563 UR154 UPS/CNRS/IRD, Toulouse, France
}

Received: 18 December 2009 - Published in Atmos. Chem. Phys. Discuss.: 12 February 2010

Revised: 9 July 2010 - Accepted: 26 July 2010 - Published: 10 August 2010

\begin{abstract}
In this paper we present the long term monitoring of ambient gaseous concentrations within the framework of the IDAF (IGAC-DEBITS-AFRICA) program. This study proposes for the first time an analysis of long-term inorganic gas concentrations (1998 to 2007) of $\mathrm{SO}_{2}, \mathrm{NO}_{2}, \mathrm{HNO}_{3}, \mathrm{NH}_{3}$ and $\mathrm{O}_{3}$, determined using passive samplers at seven remote sites in West and Central Africa. Sites are representative of several African ecosystems and are located along a transect from dry savannas-wet savannas-forests with sites at Banizoumbou (Niger), Katibougou and Agoufou (Mali), Djougou (Benin), Lamto (Cote d'Ivoire), Zoetele (Cameroon) and Bomassa (Congo). The strict control of measurement techniques as well as the validation and inter-comparison studies conducted with the IDAF passive samplers assure the quality and accuracy of the measurements. For each type of African ecosystem, the long term data series have been studied to document the levels of surface gaseous concentrations. The seasonal and interannual variability have also been analyzed as a function of emission source variations. We compared the measured West and Central African gas
\end{abstract}

concentrations to results obtained in other parts of the world. Results show that the annual mean concentrations of $\mathrm{NO}_{2}$, $\mathrm{NH}_{3}, \mathrm{HNO}_{3}$ measured in dry savannas are higher than those measured in wet savannas and forests that have quite similar concentrations. Annual mean $\mathrm{NO}_{2}$ concentrations vary from $0.9 \pm 0.2$ in forests to $2.4 \pm 0.4 \mathrm{ppb}$ in the dry savannas, $\mathrm{NH}_{3}$ from $3.9 \pm 1.4$ to $7.4 \pm 0.8 \mathrm{ppb}$ and $\mathrm{HNO}_{3}$ from $0.2 \pm 0.1$ to $0.5 \pm 0.2 \mathrm{ppb}$. Annual mean $\mathrm{O}_{3}$ and $\mathrm{SO}_{2}$ concentrations are lower for all ecosystems and range from $4.0 \pm 0.4$ to $14.0 \pm 2.8$ and from $0.3 \pm 0.1$ to $1.0 \pm 0.2 \mathrm{ppb}$, respectively. A focus on the processes involved in gas emissions from dry savannas is presented in this work, providing explanations for the high concentrations of all gases measured at the three dry savannas sites. At these sites, seasonal concentrations of all gases are higher in the wet season. Conversely, concentrations are higher in the dry season in the wet savannas. In forested regions, we measure no significant difference between wet and dry seasons. This unique database of long term gases concentrations monitoring is available at: http://medias.obs-mip.fr/idaf/.

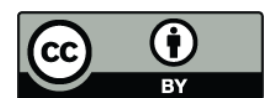

Correspondence to: $\mathrm{M}$. Adon (adonatma@yahoo.fr)

Published by Copernicus Publications on behalf of the European Geosciences Union. 


\section{Introduction}

Measurement programs play a critical role in air pollution and atmospheric chemistry studies. Moreover, long term measurement programs are crucial to documenting changes in atmospheric composition and long term monitoring allows the characterization of seasonal and interannual variability. This is particularly important in tropical regions where seasonal cycles related to natural and anthropogenic emissions sources of gases and particles are marked, resulting from seasonality of biomass burning, soil and vegetation emissions.

The international DEBITS program (Deposition of Biogeochemically Important Trace Species) was initiated in 1990 as part of the IGAC/IGBP (International Global Atmospheric Chemistry/ International Geosphere-Biosphere Programme) "core project" in order to study wet and dry atmospheric deposition in tropical regions (Lacaux et al., 2003). In 2004, DEBITS activities were positively assessed, and continue in the new IGAC II framework (task DEBITS II, Pienaar et al., 2005; Bates et al., 2006). In 2009. The DEBITS network includes about twenty five long term measuring stations evenly distributed within the tropical belt in Africa, Asia and South America. For tropical Africa, the IDAF (IGAC/DEBITS/AFRICA) project started in 1994. From the beginning the IDAF program has been recognized by INSU (Institut National des Sciences de l'Univers, in France) and the CNRS (Centre National de la Recherche Scientifique, in France) as a member of the Environmental Research Observatory (ORE, in France) network. The ORE IDAF has been given the mission of establishing a long-term measuring network to study the atmospheric composition in Africa. Since 2005, the IDAF program is also associated with the AMMA LOP (African Monsoon Mutidisciplinary Analyses/Long Observation Program, Lebel et al., 2007). Within the IDAF framework, several studies of the chemical composition of precipitation representative of African ecosystems have been published. These studies have helped to quantify the wet deposition of biogeochemically important elements and to estimate the contributions of different atmospheric sources (Galy-Lacaux and Modi, 1998; Galy-Lacaux et al., 2001; Sigha et al., 2003; Yoboue et al., 2005; Mphepya et al., 2004, 2006; Galy-Lacaux et al., 2009). To complement these studies, it is appropriate to study and quantify dry deposition fluxes. Dry deposition can be estimated, on the one hand, using continuous concentration measurements of gaseous and bulk air sampling for particulate species (ammonium and nitrate particulate content). On the other hand, realistic dry deposition velocities need to be determined for each specific site and species in order to estimate dry deposition fluxes.

In this paper, we present the long term monitoring of ambient gaseous concentrations within the IDAF program. In a second step, dry gaseous deposition fluxes will be estimated and these results are the subject of a separate paper. Our study presents an original database of ten years of measurements of five important atmospheric gases obtained within the IDAF African network at seven sites in West and Central Africa. Martins et al. (2007) have already published the long term monitoring of gases at the three IDAF sites located in South Africa. All the monitored gases play a major role in the chemistry of the atmosphere and they were included in the measurement program of the atmospheric chemistry international network DEBITS/IGAC. The monitored compounds are sulfur dioxide $\left(\mathrm{SO}_{2}\right)$, nitrogen dioxide $\left(\mathrm{NO}_{2}\right)$, nitric acid $\left(\mathrm{HNO}_{3}\right)$, ammonia $\left(\mathrm{NH}_{3}\right)$ and ozone $\left(\mathrm{O}_{3}\right)$.

It is known that the release of acidic pollutants, which include sulfur and nitrogen compounds, into the atmosphere can cause adverse health effects and have the potential to cause other environmental damage (e.g. acid rain) (Brimblecombe et al., 2007). The deposition of atmospheric compounds containing these species are thus of major importance in atmospheric studies. The oxides of nitrogen, $\left(\mathrm{NO}_{\mathrm{x}}\left(\mathrm{NO}+\mathrm{NO}_{2}\right)\right.$ mainly emitted into the atmosphere as $\mathrm{NO}$, which is subsequently transformed into $\mathrm{NO}_{2}$ and other nitrogenous species, collectively known as $\mathrm{NO}_{\mathrm{y}}$ ) play important roles in controlling the oxidative chemistry of the lower atmosphere, including regulation of the photochemical production of ozone, nitric acid and organic nitrates. Nitric acid $\left(\mathrm{HNO}_{3}\right)$ is the most important transformation product of $\mathrm{NO}_{\mathrm{x}}$. The measurement of $\mathrm{HNO}_{3}$ in ambient air is of great importance because of its significance in the acidification of the atmosphere and its control of the levels of photooxidants. Ammonia is also an important atmospheric pollutant, with a wide variety of impacts. In the atmosphere, $\mathrm{NH}_{3}$ neutralizes a great portion of the acids produced by oxides of sulfur and nitrogen. Essentially, all emitted $\mathrm{NH}_{3}$ is returned to the surface by deposition, which, since the early 1980s, has been known to be one of the primary causes of soil acidification (Sutton et al., 2009). Sulfur dioxide $\left(\mathrm{SO}_{2}\right)$ is the main cause of acid precipitation, which adversely affects natural systems as well as agriculture and building materials (Smith et al., 2001). The sulfate aerosol particles formed as a consequence of these emissions impair visibility and affect human health (Chestnut, 1995). Tropospheric ozone $\left(\mathrm{O}_{3}\right)$ is also a major environmental concern because of its adverse impacts on human health (Mc Granaham and Murray, 2003), its impact on crops and forest ecosystems (NRC, 1991; Mauzerall and Wang, 2001) and its greenhouse gas effect responsible for climate change (Hansen et al., 2002).

In the IDAF program, $\mathrm{SO}_{2}, \mathrm{NO}_{2}, \mathrm{HNO}_{3}, \mathrm{NH}_{3}$ and $\mathrm{O}_{3}$ have been measured using passive sampling. Passive samplers present a good means of addressing many measurement issues in air pollution and atmospheric chemistry. They provide a cost-effective way to monitor specific species at rural, regional and global scales. Passive samplers have been extensively tested in various international studies (Ferm and Rodhe, 1997; Ferm et al., 2005; Carmichael et al., 1996; Martins et al., 2007). Within the framework of the IDAF project, a set of passive samplers have been developed at the Laboratory of Aerology in Toulouse. 
Table 1. Geographic and ecologic characteristics of the Western and Central Africa IDAF sites.

\begin{tabular}{llllll}
\hline Ecosystem & Station & Latitude & Longitude & Elevation/m & Country \\
\hline \multirow{2}{*}{ Dry savanna } & Banizoumbou & $13^{\circ} 31^{\prime} \mathrm{N}$ & $02^{\circ} 38^{\prime} \mathrm{E}$ & 220 & Niger \\
& Katibougou & $12^{\circ} 56^{\prime} \mathrm{N}$ & $07^{\circ} 32^{\prime} \mathrm{W}$ & 290 & Mali \\
& Agoufou & $15^{\circ} 20^{\prime} \mathrm{N}$ & $01^{\circ} 29^{\prime} \mathrm{W}$ & 300 & Mali \\
\multirow{5}{*}{ Wet savanna } & Lamto & $06^{\circ} 13^{\prime} \mathrm{N}$ & $05^{\circ} 02^{\prime} \mathrm{W}$ & 105 & Cote d'Ivoire \\
& Djougou & $09^{\circ} 39^{\prime} \mathrm{N}$ & $01^{\circ} 44^{\prime} \mathrm{E}$ & 430 & Benin \\
\multirow{2}{*}{ Forest } & Zoetele & $03^{\circ} 15^{\prime} \mathrm{N}$ & $11^{\circ} 53^{\prime} \mathrm{E}$ & 720 & Cameroon \\
& Bomassa & $02^{\circ} 12^{\prime} \mathrm{N}$ & $16^{\circ} 20^{\prime} \mathrm{E}$ & 350 & Congo \\
\hline
\end{tabular}

In this paper the long term study of gas concentrations (1998 to 2007) is for the first time proposed. The determination of ambient concentrations of the inorganic gases, i.e., $\mathrm{SO}_{2}, \mathrm{NO}_{2}, \mathrm{HNO}_{3}, \mathrm{NH}_{3}$ and $\mathrm{O}_{3}$ is carried out using passive samplers at seven remote sites in West and Central Africa. First the validation of the IDAF passive sampler measurements is presented, then, an attempt to report and analyze the long-term time series of $\mathrm{NO}_{2}, \mathrm{HNO}_{3}, \mathrm{NH}_{3}, \mathrm{SO}_{2}$ and $\mathrm{O}_{3}$ is made, following a regionally representative transect through several Africa ecosystems, from dry savanna to forest through to wet savanna. The objectives are: (1) to characterize the levels of surface gas concentrations in order to provide a representative order of magnitude at the regional scale of African ecosystems and, (2) to establish the linkages between seasonal cycle and interannual variability according to the atmospheric emission sources of each studied gas. Results for West and Central African sites can then be compared to the gas concentrations measured at southern African sites (Martins et al., 2007).

\section{Experimental design}

\subsection{Sampling sites}

In the framework of the IDAF project, 10 specific sites constituting a long term monitoring network were initiated. All sites are representative of remote regions. Three types of ecosystems over West and Central Africa are monitored by multiple sites (2 pairs and 1 group of 3 ): dry savanna (Niger and Mali), wet savanna (Cote d'Ivoire and Benin), and equatorial forest (Congo and Cameroon). In South Africa, three long-term sites have also been chosen to be regionally representative of specific southern African ecosystems (Martins et al., 2007). Figure 1 shows the location of the 10 IDAF sites monitoring ambient gas concentrations in 2007. The geographical and ecological characteristics of the Western and Central African sites of interest in this study are presented in Table 1.

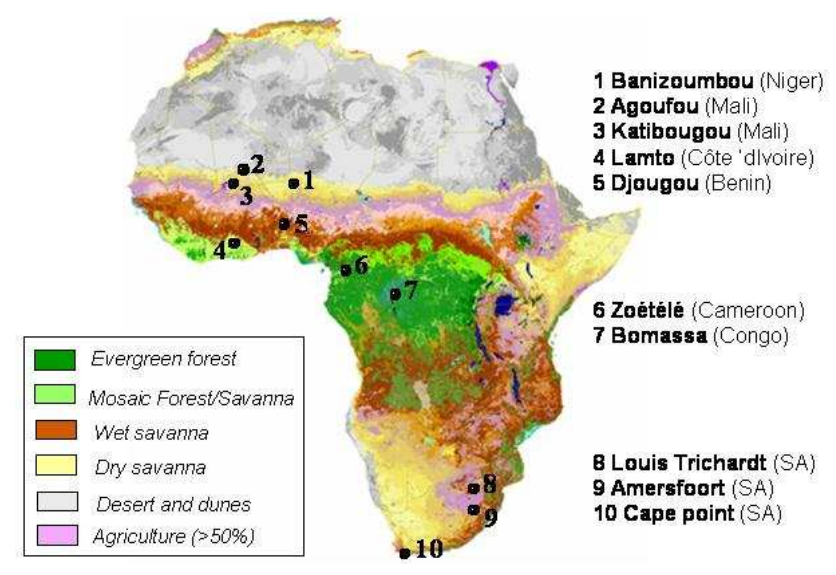

Fig. 1. Vegetation and location map of the 10 measurement stations of the IDAF network.

In general, the West and Central African climate (and its variability) is a function of the position of the Inter Tropical Convergence Zone (ITCZ), which separates the hot and dry continental air coming from the Sahara desert (Harmat$\tan$ ) from the cooler, humid maritime air masses (Monsoon) originating from the equatorial Atlantic Ocean. Extreme latitudinal positions of the ITCZ are in January (around $5^{\circ} \mathrm{N}$ ) and August (around $22^{\circ} \mathrm{N}$ ). Taking into account the position of the ITCZ and monthly mean recorded rainfall, we determined the mean dry and wet season for each of the sites studied (Table 2). The table indicates the variation of wet season duration according to site and ecosystem. The rainfall gradient extends from $358 \mathrm{~mm}$ in the dry savanna regions to $1588 \mathrm{~mm}$ in forested regions.

To briefly describe the IDAF monitoring stations: Banizoumbou is located in a rural and agro-pastoral area of the Sahelian region of Niger, approximately $60 \mathrm{~km}$ east of Niamey in southwest Niger. The climate of this region is typically Sahelian. The annual rainfall varies from $402 \mathrm{~mm}$ in 2002 to $699 \mathrm{~mm}$ in 1998 , with mean annual rainfall of $486 \mathrm{~mm}$ for the ten-year period studied. More information is available in Galy-Lacaux and Modi (1998) 
Table 2. Definition of the dry and wet seasons in IDAF stations for the 1998-2007 period. Seasonal accumulated precipitation (mm) and annual precipitation accumulation $(\mathrm{mm})$.

\begin{tabular}{|c|c|c|c|c|c|c|c|c|c|c|c|c|c|}
\hline Station & Jan & Feb & Mar & Apr & May & Jun & Jul & Aug & Sept & Oct & Nov & Dec & Total \\
\hline Banizoumbou & \multicolumn{5}{|l|}{38} & \multicolumn{4}{|c|}{451} & \multicolumn{3}{|c|}{8} & 497 \\
\hline Katibougou & \multicolumn{5}{|l|}{67} & \multicolumn{4}{|c|}{654} & \multicolumn{3}{|c|}{65} & 786 \\
\hline Agoufou & \multicolumn{5}{|l|}{18} & \multicolumn{4}{|c|}{329} & \multicolumn{3}{|c|}{11} & 358 \\
\hline Lamto & \multicolumn{3}{|l|}{188} & \multicolumn{6}{|c|}{979} & & \multicolumn{2}{|c|}{110} & 1277 \\
\hline Djougou & \multicolumn{3}{|l|}{55} & \multicolumn{6}{|c|}{1148} & & \multicolumn{2}{|r|}{2} & 1205 \\
\hline Zoetele & \multicolumn{2}{|l|}{70} & \multicolumn{7}{|c|}{1508} & & & 17 & 1595 \\
\hline Bomassa & \multicolumn{2}{|l|}{52} & \multicolumn{7}{|c|}{1481} & & & 55 & 1588 \\
\hline
\end{tabular}

Dry season

Wet season

and Galy-Lacaux et al. (2001). Katibougou is located in the Koulikoro region, at the IPR center (Institut Polytechnique Rural) approximately $60 \mathrm{~km}$ northeast of Bamako. It is representative of the Sudano-Sahelian zone. The annual rainfall varies from 585 to $1039 \mathrm{~mm}$, with an average of $771 \mathrm{~mm}$. Agoufou is part of the Malian Gourma mesoscale site $\left(14^{\circ} 5 \mathrm{~N}-17^{\circ} 5 \mathrm{~N} / 2^{\circ} \mathrm{W}-1^{\circ} \mathrm{W}\right)$ in the AMMA (African Monsoon Multidisciplinary Analysis) CATCH program (Couplage de l'Atmosphere Tropicale et du Cycle Hydrologique). It is situated towards the northern limit of the area reached by the West African monsoon. The mean annual precipitation from 2005 to 2007 is $348 \mathrm{~mm}$. A comprehensive description of the station can be found in Mougin et al. (2009). Lamto is located, in the "V-shaped Baoule" region, $160 \mathrm{~km}$ north of Abidjan and falls into the wet savanna region of Cote d'Ivoire. The Lamto Reserve covers approximately 2600 ha and is essentially made up of wet savanna with the so-called Gallery Forest along the Bandama river (Gautier, 1990). At the Lamto station, the mean annual rainfall amount is about $1269 \mathrm{~mm}$ (Yoboue et al., 2005). The Djougou station is located in northern Benin, $450 \mathrm{~km}$ from Cotonou. The site is one of the sites forming the AMMA Oueme mesoscale study. It is located in a clearing surrounded by secondary woodland, cultivated crops and fallow land that has been subjected to some small-scale vegetation burning over the five last years. It lies within the southern Sudanian vegetation zone characterized by woodland savanna. The mean annual rainfall averaged from 2005-2007 is $1205 \mathrm{~mm}$. Zoetele is located in the rainforest of southern Cameroon, $120 \mathrm{~km}$ south of Yaounde. The dense evergreen "Congo Forest" covers the entire region. Agriculture remains the dominant regional activity. At Zoetele, the average annual rainfall is $1479 \mathrm{~mm}(1998-2007)$, with a max- imum of $2162 \mathrm{~mm}$ in 1999 (Sigha et al., 2003). Bomassa is located in the natural park of Nouabale Ndoki $\left(3^{\circ} 32^{\prime} 12^{\prime \prime} \mathrm{N}-\right.$ $0^{\circ} 40^{\prime} 29^{\prime \prime} \mathrm{N} ; 15^{\circ} 28^{\prime} 26^{\prime \prime} \mathrm{E}-17^{\circ} 34^{\prime} 8^{\prime \prime} \mathrm{E}$ ) which extends from northern Congo into the Central African Republic. The site is located in the northwest Congolese equatorial forests where the altitude varies from 330 to $600 \mathrm{~m}$ and mean annual precipitation from 1450 to $1600 \mathrm{~mm}$.

Monitoring of gases at Banizoumbou, Katibougou, Lamto, Zoetele and Bomassa began in 1998. $\mathrm{NO}_{2}, \mathrm{NH}_{3}$ and $\mathrm{HNO}_{3}$ have been monitored since 1998, while measurement of ozone was started in 2001 and that of $\mathrm{SO}_{2}$ in 2002. As part of the Long term Observation Period of the AMMA program, the Djougou and Agoufou sites started operating in 2005. All measurements are still continuing at all the IDAF sites.

\subsection{Description and preparation of the passive sampler}

In the framework of the IDAF project, a set of passive samplers were developed at the Laboratory of Aerology in Toulouse according to the DEBITS procedures, based on the work of Martin Ferm (1991, 1994).

The functioning of the diffusive samplers is based on both chemical and physical processes (i.e. a chemical reaction and laminar diffuse process, respectively). The rates at which gaseous pollutants in ambient air diffuse into the sampler are controlled by the diffusion coefficients of the respective gases. At the opposite side of the inlet sampler, the gases impinge on a paper disk that has been impregnated with a specific chemical reactant and is able to trap the pollutant of interest. Since this solid support is impregnated with a small amount of absorbent material dissolved in a volatile solvent, the gases that come into contact with it impact against a large surface area and are trapped efficiently. 


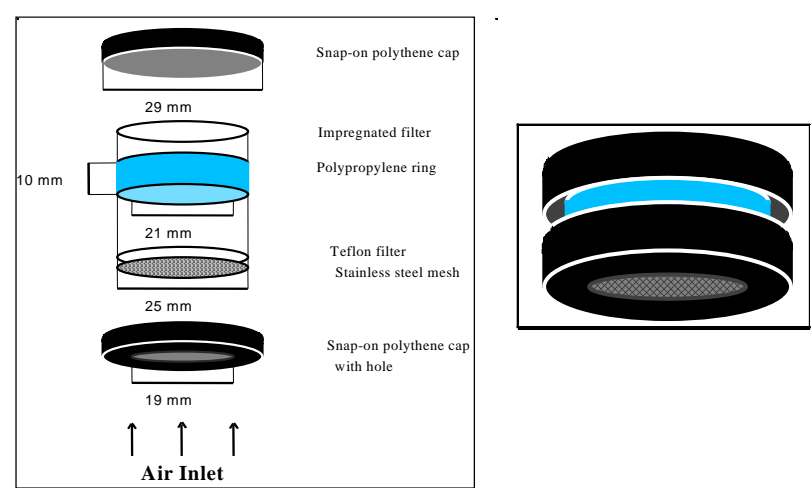

Fig. 2. Diagram of the IDAF passive diffusion sampler (adaptation from Ferm, 1991).

Figure 2 presents the typical design of the IDAF passive sampler showing series a of caps, rings and filters, each with a specific function within the sampler. To minimize internal turbulent diffusion and particle interference, a Teflon membrane (pore $1 \mu \mathrm{m}$, diameter $25 \mathrm{~mm}$ ) is used in the air inlet. The membrane is protected from mechanical damage by a stainless steel screen (thread diameter $0.08 \mathrm{~mm}$ and mesh size $0.125 \mathrm{~mm}$ ). It is possible that gaseous nitric acid and ammonia become unstable on contact with stainless steel walls, however, Ferm and Svanberg (1998) argue that the use of this stainless steel mesh during sampling is important to protect the membrane. After exposition, the samplers are stored in a fridge and the filters are removed from the samplers and analyzed to minimize any instability or oxidation of $\mathrm{NH}_{3}$ and $\mathrm{HNO}_{3}$. The concentration of the net flux of the gas through the sampler itself and trapped on the sorbent is calculated using Fick's first law of diffusion (Ferm, 2001). Following this law, the average concentration, $C_{\text {avg }}$, in $\mu \mathrm{mol} \mathrm{m}^{-3}$, is calculated using Eq. (1):

$C_{\text {avg }}=[(\mathrm{L} / \mathrm{A}) \cdot X] /(t \cdot D)$

Where $X(\mu \mathrm{mol})$ is the amount of gas pollutant trapped on the paper disk (corrected for the blank) after exposure time $t(\mathrm{~s})$, $D\left(\mathrm{~m}^{2} \mathrm{~s}^{-1}\right)$ is the diffusion coefficient of the gas in air, $L(\mathrm{~m})$ is the diffusion path length, and $A\left(\mathrm{~m}^{2}\right)$ is the cross-sectional area of the diffusion path.

The average concentration can be expressed in ppb using the Eq. (2).

$\left.C_{\mathrm{avg}}(\mathrm{ppb})\right)=[(\mathrm{L} / \mathrm{A}) \cdot X \cdot R \cdot T] /(t \cdot D \cdot P)$

Where $T$ is the average temperature during the sampling period $(\mathrm{K}), R$ is the ideal gas constant $(R=$ $0.082061 \mathrm{~atm} \mathrm{k}^{-1} \mathrm{~mol}^{-1}$ ) and $P$ is the mean atmospheric pressure during the sampling period $(P=1 \mathrm{~atm}) . L / A$ is the coefficient of air resistance and depends on the sampler size and geometry.
In the IDAF network we define four samplers which differ by their color and their coating solutions: grey for nitrogen dioxide $\left(\mathrm{NO}_{2}\right)$, black for nitric acid $\left(\mathrm{HNO}_{3}\right)$ and sulfur dioxide $\left(\mathrm{SO}_{2}\right)$, white for ammonia $\left(\mathrm{NH}_{3}\right)$ and a mixture of black and grey for ozone $\left(\mathrm{O}_{3}\right)$.

Samplers are prepared in the laboratory in the following manner: $25 \mathrm{~mm}$ diameter cellulose filters (Whatman 40) are cut to fit into the sampler bottom and are submitted to three washes with deionised water in an ultrasonic bath, and a further fourth wash with methanol (15 min each). After drying in a stove at $50^{\circ} \mathrm{C}$, the filters are then impregnated with different coating solutions for $2 \mathrm{~h}$, and dried again before being put into the samplers. Coating solutions have been specifically chosen to absorb and convert targeted species into another stable species with which other pollutants do not interfere. In our study, we adopted some referenced works of passive sampler validation to choose the best coating solutions, which are presented in Table 3. References are: for $\mathrm{SO}_{2}$ and $\mathrm{NO}_{2}$ (Ayers et al., 1998; Ferm and Rodhe, 1997; Ferm and Svanberg, 1998), for $\mathrm{NH}_{3}$ (WMO TD No.829), for $\mathrm{HNO}_{3}$ (Al-Ourabi, 2002) and for $\mathrm{O}_{3}$ (Koutrakis et al., 1993). All other components of the passive sampler used for storage and transport underwent similar cleaning treatments. At all times rubber gloves were used to handle passive samplers in order to avoid contamination.

\subsection{Sampling and analysis}

\subsubsection{Sampling procedure}

In the IDAF measuring network, the Laboratory of Aerology is in charge of the preparation and the analysis of passive samplers used at the seven western and central African sites. Initially, the passive samplers are supplied ready for use in a sealed container, loaded with a filter treated for a nominated pollutant gas. Each two months, they are sent to the stations with a technical sheet (dates of installation/removal, temperature during exposition, etc) to local operators. Passive gas samplers are then exposed for a one month period at the remote rural sites of the network. They are mounted under a plastic support plate to avoid direct impact from wind transport and splashing from precipitation. The support is attached to a pole at a height between 1.5-2 $\mathrm{m}$ for the savanna sites while in the forest ecosystem, the sampling height is about $3 \mathrm{~m}$. All the samplers are exposed in pairs in order to ensure the reproducibility of results and to reduce data loss if a sampler suffers interference (e.g. $\mathrm{HNO}_{3}$ and $\mathrm{NO}_{2} ; \mathrm{NO}_{2}$ and $\mathrm{O}_{3} ; \mathrm{HNO}_{3}$ and $\mathrm{NH}_{3}, \mathrm{NH}_{3}$ and particulate ammonium, bacterial decomposition, etc.) (Fig. 2). For each set of samplers, blank samples are kept sealed in the film container to be used as field blanks which are also returned for analysis. After exposure, passive samplers are sent back to the Laboratory of Aerology and stored in a fridge $\left(4^{\circ} \mathrm{C}\right)$ to minimize possible bacterial decomposition or other reactions. To avoid positive artefacts (particulate ammonium contamination) for 
Table 3. Coating solutions and chemical reactions of the $\mathrm{HNO}_{3}, \mathrm{SO}_{2}, \mathrm{NO}_{2}, \mathrm{NH}_{3}, \mathrm{O}_{3}$ IDAF passive samplers (WMO TD No: 829; AlOurabi, 2002).

\begin{tabular}{|c|c|c|}
\hline Gas (Colour of the sampler) & Coating solution & Chemical reaction on the filter \\
\hline $\mathrm{HNO}_{3}$ and $\mathrm{SO}_{2}$ (Black) & $0.5 \mathrm{~g} \mathrm{NaOH}$ in $50 \mathrm{~mL}$ methanol $(\mathrm{pH}>12)$ & $\begin{array}{l}\mathrm{HNO}_{3}(\mathrm{~g}) \mathrm{OH}^{-} \rightarrow \mathrm{NO}_{3}^{-}+\mathrm{H}_{2} \mathrm{O} \\
2 \mathrm{SO}_{2}(\mathrm{~g})+4 \mathrm{OH}^{-}+\mathrm{O}_{2} \rightarrow 2 \mathrm{H}_{2} \mathrm{O}+2 \mathrm{SO}_{4}^{-2}\end{array}$ \\
\hline $\mathrm{NO}_{2}$ (Grey) & $0.44 \mathrm{~g} \mathrm{NaOH}+3.95 \mathrm{~g} \mathrm{NaI}$ in $50 \mathrm{~mL}$ methanol $(\mathrm{pH}>12)$ & $2 \mathrm{NO}_{2}(\mathrm{~g})+3 \mathrm{I}^{-} \rightarrow 2 \mathrm{NO}_{2}^{-}+\mathrm{I}_{3}^{-}$ \\
\hline $\mathrm{NH}_{3}$ (White) & $1.0 \mathrm{~g}$ citric acid in $50 \mathrm{~mL}$ methanol & $\mathrm{NH}_{3}(\mathrm{~g})+\mathrm{H}^{+} \rightarrow \mathrm{NH}_{4}^{+}$ \\
\hline $\mathrm{O}_{3}$ (Grey \& black) & $\begin{array}{l}0.25 \mathrm{~g} \mathrm{NaNO}_{2}+\mathrm{O} .25 \mathrm{~g} \mathrm{~K}_{2} \mathrm{CO}_{3}+0.5 \mathrm{ml} \\
\text { redistilled glycerol in } 50 \mathrm{ml} \text { water }\end{array}$ & $\mathrm{O}_{3}(\mathrm{~g})+\mathrm{NO}_{2}^{-} \rightarrow \mathrm{NO}_{3}^{-}+\mathrm{O}_{2}$ \\
\hline
\end{tabular}

the $\mathrm{NH}_{3}$ sampler, just after exposure in the field we remove the inlet part of the sampler (the cap with hole, the steel mesh and the Teflon filter) to be replaced by a closed cap. Delon et al., 2010, provides a new $\mathrm{NH}_{3}$ emission inventory for the Sahelian region. This emission budget appears to be in good agreement with IDAF $\mathrm{NH}_{3}$ measurements. So, we can assume that artefacts are not significant.

Before analysis of all passive samplers, the impregnated filters are removed from the samplers to be prepared for analysis using ion chromatography. Then, as part of the long term measurement network, samplers are recycled. All parts are cleaned and supports are reloaded with freshly impregnated filters before being mailed again to the site operators. The Laboratory of the School for Chemistry and Biochemistry of the North-West University in South Africa is tasked with the preparation and the analysis of the passive samplers used at the three IDAF sites in South Africa (Martins et al., 2007).

\subsubsection{Chemical analysis}

Inorganic anions and cations, i.e., sulfate, nitrate, nitrite and ammonium captured on impregnated filters of the gas passive samplers are determined by ion chromatography (see chemical reactions in Table 3). Filters are extracted in $10 \mathrm{ml}$ of $18 \mathrm{M} \Omega \mathrm{cm}$ water by ultrasonic stirring $(15 \mathrm{~min})$. The laboratory is equipped with a DIONEX DX500 and ICS 1000 ion chromatograph (IC) with two automatic samplers (AS50). The determination of anions on the DX500 uses a gradient pump (GP40), with a conductivity detector (CD20), a DIONEX Ionpac AS-11 and AG-11 as pre-column. For ammonium detection, an ICS 1000 in an isocratic mode with CG12A and CS12A as pre-column and column, is used. The eluents are $\mathrm{NaOH}$ and MSA for anions and cations, respectively. Certified ionic standards were used for IC calibration. The quality of measurements depends not only on the sampler but also on the analysis (Galy-Lacaux and Modi, 1998) and the standardized and accredited procedures. Since 1996 the analytical Laboratory of Aerology has participated in the quality control inter-comparison program organized twice a year by the World Meteorological Organiza- tion (WMO). According to the results of our quality assurance program, analytical precision is estimated to be $5 \%$ or better for all ions, within the uncertainties of all measured values presented here. All the results from our laboratory, referenced as the participant number 700106, are available at: http://qasac-americas.org/.

For each month of measurement, a field blank is included with the samplers sent into the field. The time between field deployment and analysis is the same for both the blanks and experimental samples. Over the studied period, 23 analytical series of measurements have been performed in IC and a total of 230 blanks for each gas have been analyzed. Detection limits for each trace gas were calculated from field blanks and found to be $0.07 \pm 0.03 \mathrm{ppb}$ for $\mathrm{HNO}_{3}, 0.2 \pm 0.1 \mathrm{ppb}$ for $\mathrm{NO}_{2}, 0.7 \pm 0.2 \mathrm{ppb}$ for $\mathrm{NH}_{3}, 0.05 \pm 0.03 \mathrm{ppb}$ for $\mathrm{SO}_{2}$ and $0.1 \pm 0.1 \mathrm{ppb}$ for $\mathrm{O}_{3}$. The analysis of our database shows that $12 \%$ of $\mathrm{HNO}_{3}, 4 \%$ of $\mathrm{NO}_{2}$ and $13 \%$ of $\mathrm{SO}_{2}$ measurements were below the detection limit. Data below detection limits were removed from the final database.

All samples are collected in duplicate. The average of the two duplicate samples is used in all cases except when contamination of one of the samples is suspected (less then 5\% of all data). To give an indication of the precision of this sampling technique, the covariance of all duplicate samples was calculated for the ten year period (1998-2007). The reproducibility was found to be $20 \%, 9.8 \%, 14.3 \%, 16.6 \%$ and $10 \%$ for $\mathrm{HNO}_{3}, \mathrm{NO}_{2}, \mathrm{NH}_{3}, \mathrm{SO}_{2}$ and $\mathrm{O}_{3}$ respectively. These results compare well with those reported by Martins et al. (2007), at the southern Africa sites, for the same pollutants $\left(20 \%, 8.3 \%, 15.3 \%, 16.6 \%\right.$ and $2.4 \%$ for $\mathrm{HNO}_{3}$, $\mathrm{NO}_{2}, \mathrm{NH}_{3}, \mathrm{SO}_{2}$ and $\mathrm{O}_{3}$, respectively). These values are also in accordance with other data presented in the literature especially for $\mathrm{NO}_{2}, \mathrm{NH}_{3}$ and $\mathrm{SO}_{2}$ (Carmichael et al., 2003; Ayers et al., 1998; Campos et al., 2010; Ferm and Rodhe, 1997). However, the IDAF ozone passive sampler presents a higher reproducibility value, attributable to the low ozone concentrations measured in the African remote sites (see Sect. 3.3). These results are in agreement with the variations found between different laboratories for duplicate analysis equal to $\pm 25 \%$, which is acceptable for indicative 
monitoring (Stevenson et al., 2001) and within the accuracy limit recommended by the European Union directive (EU, 1999).

\subsection{Validation of IDAF passive samplers}

The use of passive samplers in the IDAF network was preceded by several tests and validations.

\subsubsection{Determination of the $L / A$ parameter}

We first optimized the determination of the $L / A$ ratio (Eq. 2), which is dependent on the sampler geometry. $L / A$ is defined by the following sum:

$L / A=(L a / A a+L f / A f+L g / A g+L c / A t)$

where $L a$ is the ring length $\left(10^{-2} \mathrm{~m}\right), A a$ the surface of the ring section $\left(3.46 \times 10^{-4} \mathrm{~m}^{2}\right), L f$ the thickness of the teflon filter $\left(175 \times 10^{-6} \mathrm{~m}\right), A f$ the teflon filter area permeable to air $\left(2.27 \times 10^{-4} \mathrm{~m}^{2}\right), L g$ is the thickness of the stainless steel grid $\left(90 \times 10^{-6} \mathrm{~m}\right), \mathrm{Ag}$ is the grid surface permeable to air $\left(9.9 \times 10^{-5} \mathrm{~m}^{2}\right), L c$ the thickness of the laminar boundary layer and $A t$ is the surface of the inlet hole $\left(2.84 \times 10^{-4} \mathrm{~m}^{2}\right)$. $L c$ is a key parameter in the calculation of the gas concentration in the atmosphere. In the IDAF validation phase, we experimentally determined the value of $L c$ for our passive samplers. For each specific gas, two passive samplers were mounted and exposed at the same moment: one with the impregnated filter normally mounted at the bottom of the sampler and one with the impregnated filter directly at the inlet of the sampler. The analysis of the two samplers allow the calculation of $L c$ and thus the final determination of $L / A$. The experiment was performed in the field on the instrumented terrace of Laboratory of Aerology in Toulouse at low wind speed. This is consistent with the wind speeds measured at the IDAF sites, which are generally low: around $1 \mathrm{~m} / \mathrm{s}$ at a height of $2 \mathrm{~m}$. The wind is an important factor as molecular diffusion can change from a laminar to a turbulent regime and results may be overestimated as a result of the dramatic increase in the amount of molecules collected. A sufficient number of experiments allowed us to eliminate some outliers and thus overcome problems related to experimental conditions. A total of two hundred samplers have been exposed: 60 black samplers for $\mathrm{HNO}_{3}$ and $\mathrm{SO}_{2} ; 60$ grey samplers for $\mathrm{NO}_{2}, 40$ white samplers for $\mathrm{NH}_{3}$ and 40 grey and black samplers for $\mathrm{O}_{3}$. Considering the concentration levels generally measured in urban areas, we have chosen exposure of 15 days for all passive samplers except for ammonia passive sampler (7 days). A synthesis of all the results is presented in Table 4. The $L / A$ value for the IDAF passive samplers is estimated to be $47.5 \pm 1.6 \mathrm{~m}^{-1}$. The corresponding thickness value of the laminar boundary layer $(L c)$ is equal to $4.8 \pm 0.5 \mathrm{~mm}$ (AlOurabi, 2002).
Table 4. Synthesis of $L / A$ and $L c$ experimental determination (AlOurabi, 2002).

\begin{tabular}{llllllll}
\hline Gas & $\mathrm{NO}_{2}$ & $\mathrm{NH}_{3}$ & $\mathrm{HNO}_{3}$ & $\mathrm{SO}_{2}$ & $\mathrm{O}_{3}$ & Mean & $\begin{array}{l}\text { Standard } \\
\text { Deviation }\end{array}$ \\
\hline$L c(\mathrm{~mm})$ & 5.2 & 4.5 & 5.3 & 4.6 & 4.3 & $\mathbf{4 . 8}$ & 0.5 \\
$L / A\left(\mathrm{~m}^{-1}\right)$ & 48.9 & 46.5 & 49.5 & 46.8 & 45.7 & $\mathbf{4 7 . 5}$ & 1.6 \\
\hline
\end{tabular}

\subsubsection{Inter-comparison and quality control for passive samplers}

To ensure that the west and central African passive sampling monitoring network delivers reliable results, a number of inter-comparison tests studies have been performed within the IGAC-DEBITS program. Also some comparisons were initiated in collaboration with the IVL (Swedish Environmental Research Institute) (accredited lab). In order to assess the performance and reliability of IDAF passive samplers a study was undertaken at different sites in Toulouse, France (1998-2000). The accuracy of the IDAF passive sampling measurements was determined during a two week experiment in the city, by comparing readings performed by a set of MEGATEC continuous analyzers for $\mathrm{NO}_{2}$ (model 42C-TL, chemiluminescence), $\mathrm{O}_{3}$ (model 49i, UV photometry) and $\mathrm{SO}_{2}$ (model 43i, pulsed UV fluorescence). Figure $3 \mathrm{a}, \mathrm{b}$ and $\mathrm{c}$ presents the comparisons of gas concentrations measured by passive samplers (integration over 15 days) and active analyzers. All the gases showed a good correlation between the two methods of measurements. $\mathrm{NO}_{2}$, $\mathrm{SO}_{2}$ and $\mathrm{O}_{3}$ have a mean comparative ratio of 1:0.9, 1:0.8 and 1:0.7, respectively, between passive and active sampling methods. The correlations are high with $R^{2}=0.95$ for $\mathrm{NO}_{2}$, $R^{2}=0.8$ for $\mathrm{O}_{3}$ and $R^{2}=0.9$ for $\mathrm{SO}_{2}$. The lowest correlation is for $\mathrm{O}_{3}$ and can be explained by the indirect $\mathrm{O}_{3}$ determination using the passive sampler method and the overall oxidation potential of the atmosphere. For the ozone passive sampler, we also performed a validation test in Benin at the Djougou site, where continuous ozone concentrations were measured with an active analyzer during the AMMA experiment (Serça et al., 2007). IDAF passive samplers and active analyzer measurements were compared for the wet season from April to September 2006 (Fig. 3d). Observed results show that monthly mean ozone concentrations range between 10 to $25 \mathrm{ppb}$. For this range, the maximum difference observed between the two techniques (passive/active) is about $6 \%$.

In a second phase of validation, the IDAF passive samplers participated in the pilot Urban Meteorology and Environment (GURME) measurement program initiated by WMO/GAW. This passive sampler project was carried out in collaboration with, and as a component of the IGAC DEBITS program. Measurements from 1998 to 2000 from the 

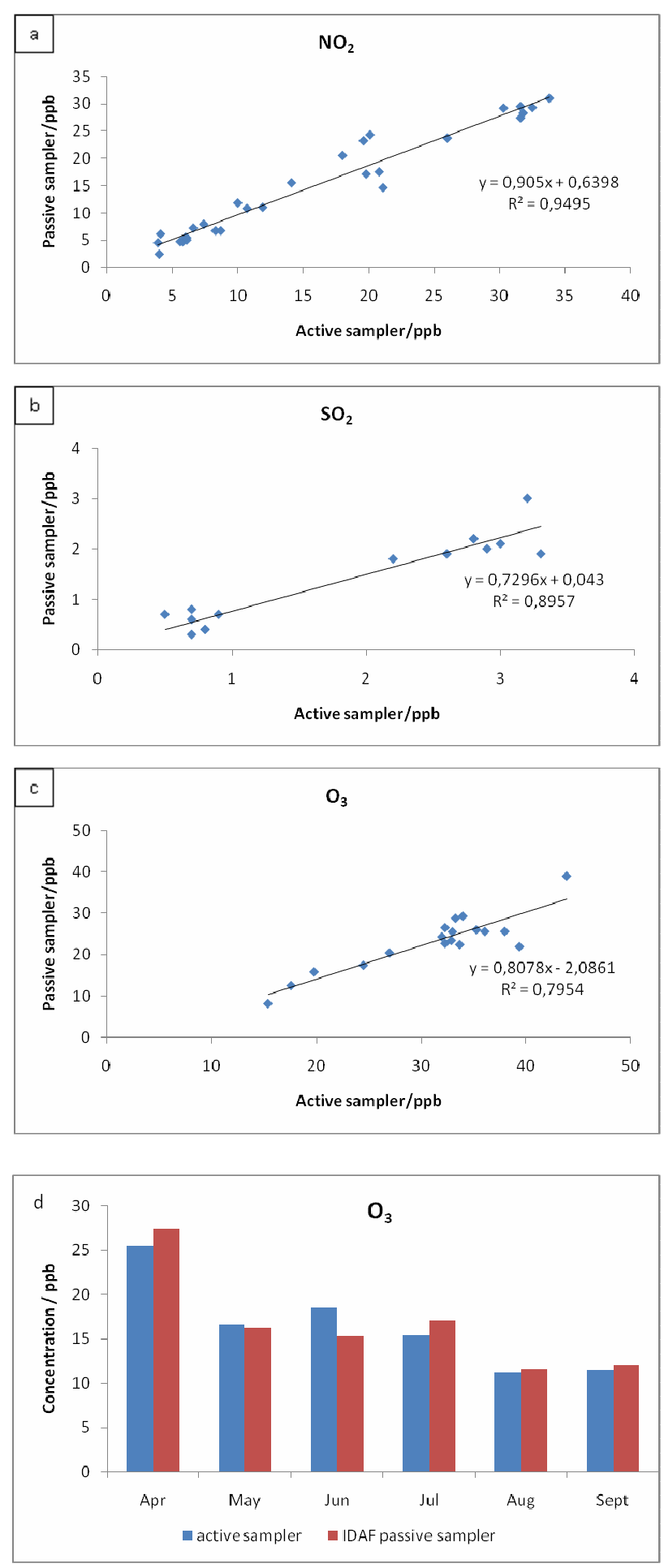

Fig. 3. Comparison of active and passive $\mathrm{NO}_{2}$ (a), $\mathrm{SO}_{2}$ (b), $\mathrm{O}_{3}$ (c) measurements (ppb) at Toulouse (France) from 1998 to 2000; $\mathrm{O}_{3}$ (d) measurements at Djougou (Benin) in 2006.

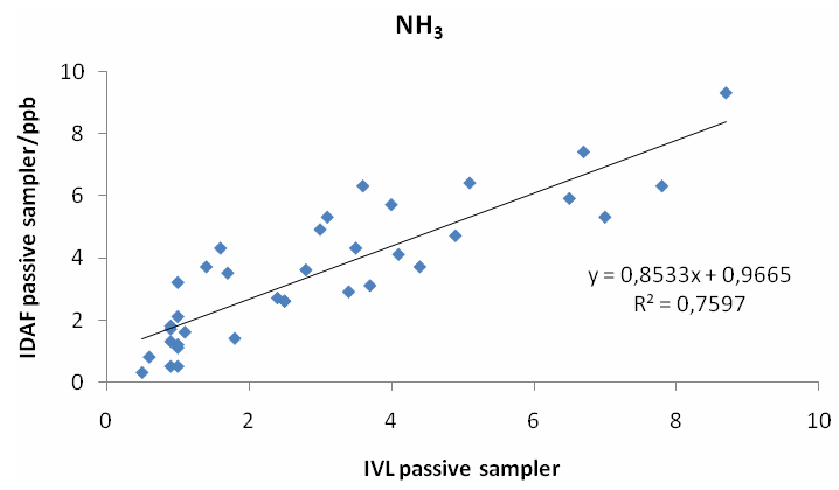

Fig. 4. Comparison of the IDAF and IVL NH3 passive samplers (GURME project) exposed at IDAF stations from 1998 to 2000.

Banizoumbou (Niger), Zoetele (Cameroon), Lamto (Cote d'Ivoire) and Cape Point (South Africa) sites were used in this test (Carmichael et al., 2003). At these sites IVL samplers were exposed for one month in parallel to the IDAF samplers (Ferm and Rodhe, 1997; Carmichael et al., 2003). Wind conditions at the sites are characterized by low wind speed with measured values ranging from less than $1 \mathrm{~m} \mathrm{~s}^{-1}$ in the forest of Cameroon to $3 \mathrm{~m} \mathrm{~s}^{-1}$ in the dry savanna of Niger. IVL samplers were analyzed in the IVL accredited laboratory and IDAF samplers were analyzed in the analytical laboratory of Aerology. This study allowed the comparison of $\mathrm{SO}_{2}, \mathrm{NH}_{3}$ and $\mathrm{O}_{3}$ measurements with about 35 samples for each gas. The IVL and the IDAF measurements compare well with acceptable correlation coefficients according to the measurement uncertainties. Figure 4 details the results for $\mathrm{NH}_{3}$, and the correlation $\left(R^{2}=0.76\right)$ indicates an accuracy of $24 \%$ accuracy between measurements from the two samplers.

Moreover, the literature indicates that these samplers have been extensively tested in various international studies. Several tests were carried out to compare absorption efficiency and to select the most adequate solution with which to impregnate the filters used in the passive sampler exposed to conditions typical of tropical air. For $\mathrm{HNO}_{3}, \mathrm{SO}_{2}, \mathrm{NO}_{2}$ and $\mathrm{NH}_{3}$ we cite Ferm and Rodhe (1997) and Ferm et al. (2005). Cruz et al. (2004) validate $\mathrm{SO}_{2}$ passive samplers for tropical industrial and urban air in South America. Passive samplers have been also extensively used in tropical Asia and South America (Carmichael et al., 1996, 2003; Gupta et al., 2003; Tidblad et al., 2007). In Africa, the first studies mainly concerning the South African passive sampler network have been recently published (Zunckel et al., 2004; Martins et al., 2007; Josipovic et al., 2007).

Diffusive samplers have many advantages in the field, including no need for calibration, sampling tubing, electricity or technicians. The samplers are small, light, reusable, costefficient and soundless. The outcome of the above mentioned validation and inter-comparison studies of passive sampling 
assures the quality and control of its sampling and the analytical protocols used make it a viable means of obtaining credible atmospheric data at remote sites on a long term basis. According to the detection limits, reproducibility and inter-comparison studies between different techniques, we argue that the IDAF passive samplers are adequate to perform long term monitoring at remote African sites. These measurements are also well adapted to detect seasonal trends and to be compared with measurements from other regions.

\section{Results and discussion}

Atmospheric concentrations of $\mathrm{NO}_{2}, \mathrm{HNO}_{3}, \mathrm{NH}_{3}, \mathrm{SO}_{2}$ and $\mathrm{O}_{3}$ are measured as part of the IDAF network on a monthly basis. Passive sampling observations at the West and Central African sites have been taken over a ten year period from 1998 to 2007. Table 5 presents a synthesis of the mean annual gas concentrations for all the IDAF sites. Measurements at the South African IDAF sites have been performed from 1995 to 2005 (Martins et al., 2007). Results were calculated using only the approved data points (in brackets in Table 5). Considering the entire database, less than $10 \%$ of the returned samplers were below the detection limit.

This study presents monthly, seasonal, annual and interannual variations for each gas as a function of the sites representative of each ecosystem. The analysis of the global database provides, for the first time, the levels of important trace gas concentrations for remote African sites on a long term basis. The seasonal and annual cycles of gas concentrations will be discussed in relation to climatology and gas emissions sources. Comparative studies along the ecosystems transect, i.e., dry savannas-wet savannas-forests will highlight the predominant atmospheric processes in terms of gaseous atmospheric sources in each ecosystem.

\subsection{Nitrogen dioxide $\left(\mathrm{NO}_{2}\right)$}

Figures 5 presents the monthly $\mathrm{NO}_{2}$ evolution measured in the dry savannas of Niger and Mali (5a: Banizoumbou, Katibougou, Agoufou), in the wet savannas of Cote d'Ivoire and Benin (5b: Lamto, Djougou) and in the equatorial forests of Cameroon and Congo (5c: Zoetele, Bomassa). Vertical bars indicate the standard deviation calculated over the study period (1998-2007). Decadal-average monthly evolution of precipitation is superimposed on the monthly $\mathrm{NO}_{2}$ concentrations.

For the first time, this study reports the marked seasonal cycle of $\mathrm{NO}_{2}$ surface concentration in arid and semi-arid African areas (Fig. 5a). It allows the quantification of concentration levels with a strong level of confidence, using the 10 -year means calculated from measurements at the two Sahelian sites. The dry savannas are characterized by a dry season from October to May and a wet season from June to September. The month of May represents the transi-
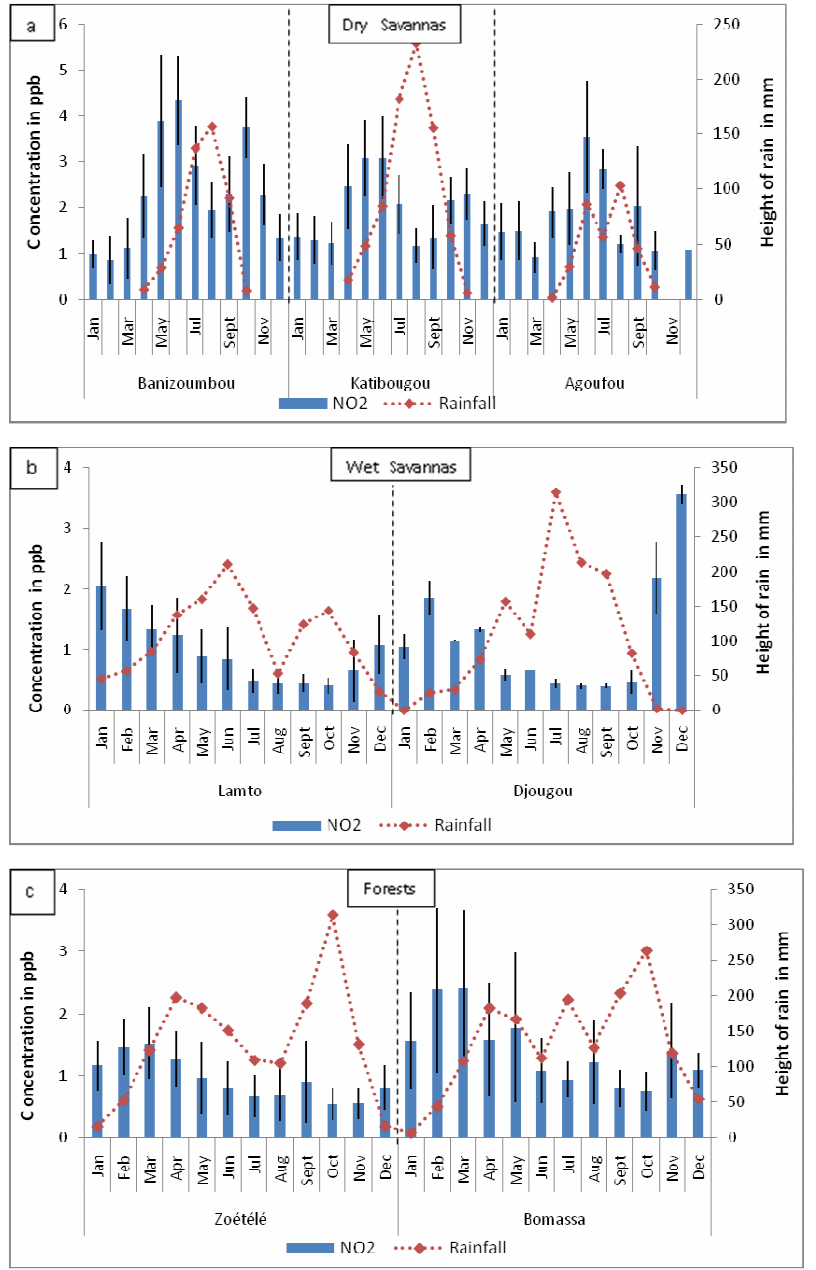

Fig. 5. Evolution of monthly $\mathrm{NO}_{2}$ concentrations on the transect dry savannas (a), wet savannas (b), forests (c).

tion from the dry to the wet season. Monthly mean $\mathrm{NO}_{2}$ concentrations over the ten years of measurements range between $0.9 \pm 0.3 \mathrm{ppb}$ and $4.3 \pm 1.0 \mathrm{ppb}$ at Banizoumbou, $1.2 \pm 0.5 \mathrm{ppb}$ and $3.1 \pm 0.9 \mathrm{ppb}$ at Katibougou, $0.9 \pm 0.3 \mathrm{ppb}$ and $3.5 \pm 1.2 \mathrm{ppb}$ at Agoufou (for which only 3 years of measurements are available). Variations of monthly $\mathrm{NO}_{2}$ concentrations present the same pattern at the three dry savanna sites. Monthly concentrations begin to increase significantly from April, the first month of rain. A first maximum is obtained in May/June and is consistent with the emission of biogenic NO emissions from nitrogen accumulated (as ammonium and nitrite ions) in soils during the long dry season as a result of traditional agricultural practices, such as grazing, manure application and decomposition of crop residues, followed by rain on the sandy soils of this area (Jaegle et al., 2004). In fact, after the first rains occur in April-May announcing the wet season, bacterial nitrification is activated and lead to nitrogen consumption and consequently to the release of large pulses of NO (Davidson, 1992; Laville et al., 
Table 5. Mean annual concentrations (in ppb) at IDAF sites and the number of acceptable duplicates (in brackets) .

\begin{tabular}{|c|c|c|c|c|c|c|}
\hline & Station (period) & $\mathrm{NO}_{2}$ & $\mathrm{HNO}_{3}^{* * *}$ & $\mathrm{NH}_{3}$ & $\mathrm{O}_{3}^{*}$ & $\mathrm{~S}_{2}^{* *}$ \\
\hline & \multicolumn{6}{|l|}{ West and Central African sites } \\
\hline & Banizoumbou (98-07) & $2.4 \pm 0.4(113)$ & $0.5 \pm 0.2(112)$ & $6.3 \pm 2.0(112)$ & $11.9 \pm 2.3(76)$ & $0.6 \pm 0.2(66)$ \\
\hline \multirow[t]{2}{*}{ Dry Savannas } & Katibougou (98-07) & $1.9 \pm 0.3(117)$ & $0.4 \pm 0.1(116)$ & $6.6 \pm 1.0(113)$ & $12.6 \pm 2.2(73)$ & $0.6 \pm 0.2(68)$ \\
\hline & Agoufou (05-07) & $1.8 \pm 0.4(28)$ & $0.5 \pm 0.1(28)$ & $7.4 \pm 0.8(25)$ & $12.2 \pm 2.6(23)$ & $1.0 \pm 0.2(26)$ \\
\hline \multirow[t]{2}{*}{ Wet Savannas } & Lamto (98-07) & $1.0 \pm 0.3(115)$ & $0.3 \pm 0.1(116)$ & $4.0 \pm 1.2(112)$ & $10.9 \pm 1.8(78)$ & $0.5 \pm 0.2(67)$ \\
\hline & Djougou (05-07) & $1.2 \pm 0.1(30)$ & $0.4 \pm 0.2(30)$ & $3.9 \pm 1.4(27)$ & $14.0 \pm 2.8(29)$ & $0.8 \pm 0.3(29)$ \\
\hline \multirow[t]{3}{*}{ Forests } & Zoetele (98-07) & $0.9 \pm 0.2(112)$ & $0.2 \pm 0.1(113)$ & $4.2 \pm 0.9(103)$ & $4.8 \pm 1.0(73)$ & $0.3 \pm 0.1(65)$ \\
\hline & Bomassa (98-06) & $1.4 \pm 0.4(83)$ & $0.3 \pm 0.1(81)$ & $4.7 \pm 1.7(76)$ & $4.0 \pm 0.4(45)$ & $0.4 \pm 0.2(44)$ \\
\hline & Southern African sites & & & & & \\
\hline \multirow[t]{2}{*}{ Dry Savannas } & Amersfoort (97-05) & $2.5 \pm 1.0(105)$ & $0.9 \pm 0.5(26)$ & $1.2 \pm 0.7(85)$ & $27 \pm 8.3(89)$ & $2.8 \pm 1.1(10)$ \\
\hline & Louis Trichardt (95-05) & $0.7 \pm 0.4(71)$ & $0.2 \pm 0.1(27)$ & $1.2 \pm 0.7(65)$ & $35 \pm 8.6(72)$ & $0.8 \pm 0.7(70)$ \\
\hline Coastal/Continental & Cape Point (95-05) & $1.2 \pm 0.6(114)$ & $0.5 \pm 0.2(29)$ & $1.5 \pm 0.7(120)$ & $27 \pm 7.3(114)$ & $0.7 \pm 0.4(106)$ \\
\hline
\end{tabular}

* In West and Central Africa, $\mathrm{O}_{3}$ starts monitoring in 2001 and

** $\mathrm{SO}_{2}$ in 2002.

*** In South Africa, $\mathrm{HNO}_{3}$ starts in 2003.

2005; Ludwig et al., 2001; Williams et al., 1992; Yienger and Levy, 1995). $\mathrm{NO}$ is rapidly converted into $\mathrm{NO}_{2}$ in the atmosphere through oxidative processes. After excess nitrogen is consumed, wet season NO emissions decrease but remain at relatively high levels compared to the dry season (Serça et al., 1998). A second maximum occurs in the beginning of the dry season in October-November in Katibougou and Banizoumbou. It is associated with biomass burning sources active in the Northern Hemisphere during this period (Jaegle et al., 2004). In Agoufou (Mali), a second maximum is observed in September. As a result of the more northerly latitude of this site, we assume that biomass burning has a smaller influence than for the other dry savannas sites. This second peak is possible related to rain events occurring after several dry days.

In the dry savannas, mean seasonal concentrations are $3.1 \pm 0.6 \mathrm{ppb}, 2.1 \pm 0.5 \mathrm{ppb}$ and $2.5 \pm 0.7 \mathrm{ppb}$ in the wet season; and $1.9 \pm 0.5 \mathrm{ppb}, 1.8 \pm 0.2 \mathrm{ppb}$ and $1.4 \pm 0.4 \mathrm{ppb}$ in the dry season for the Banizoumbou, Katibougou and Agoufou sites, respectively. Monthly concentrations are higher in the wet season at all sites. Mean annual $\mathrm{NO}_{2}$ concentrations are $2.4 \pm 0.4 \mathrm{ppb}, 1.9 \pm 0.3 \mathrm{ppb}$ and $1.8 \pm 0.4 \mathrm{ppb}$ at Banizoumbou, Katibougou, and Agoufou, respectively (see Table 5). The interannual variability for the ten year period is about $19 \%$, $15 \%$ and $24 \%$ for the three Sahelian sites. No specific trend in the variability is observed. The analysis of interannual variability clearly reflects the potential variation of the intensity of atmospheric sources associated with a second important factor, i.e. the variation of annual rainwater depth. The amount of water and its temporal variation is a determinant of soil $\mathrm{NO}_{\mathrm{x}}$ emissions (Johansson and Sanhueza, 1988; Davidson, 1992; Scholes et al., 1997). As part of the AMMA program (African Monsoon Multidisciplinary Analysis), Delon et al. (2008) and Stewart et al. (2008) studied soil $\mathrm{NO}_{\mathrm{x}}$ emis- sion variation as a function of spatial patterns of rainfall for the month of August 2006 in the Sahelian region. Modeling studies and measurements presented in these papers clearly show strong $\mathrm{NO}_{\mathrm{x}}$ emissions in the Sahel during the wet season, strongly dependent on soil moisture and on the temporal distribution and rates of precipitation. The analysis of rainfall in the Sahel shows a strong spatial and temporal variability (Balme et al., 2006) which influences the interannual variability of $\mathrm{NO}_{2}$ concentration. However, the weight of each process is somewhat difficult to estimate. Jaegle et al. (2004) show that monthly top down GOME soil $\mathrm{NO}_{\mathrm{x}}$ emissions allow a good representation of the temporal variation with a maximum in June-July. Delon et al. (2008) and Stewart et al. (2008) with other methods confirm the strong potential for semi-arid areas to emit large amount of $\mathrm{NO}_{\mathrm{x}}$. In the vast areas covered by dry ecosystems, the long term monitoring of the IDAF sites in Mali and Niger similarly provides evidence for the large influence of microbial soil emissions of $\mathrm{NO}_{\mathrm{X}}$.

Monthly mean $\mathrm{NO}_{2}$ concentrations in wet savannas range from $0.4 \pm 0.1 \mathrm{ppb}$ to $2.0 \pm 0.7 \mathrm{ppb}$ in Lamto (mean for the 10 years of measurements) and from $0.4 \pm 0.1 \mathrm{ppb}$ to $3.6 \pm 0.2 \mathrm{ppb}$ in Djougou (mean for 3 years of measurements) (Fig. 5b). In general, atmospheric $\mathrm{NO}_{2}$ concentrations slowly decrease from January to October. Thereafter, monthly mean concentrations increase until a maximum is observed in December. The Djougou site in Benin shows highest concentrations in November-December, while at Lamto highest concentrations are observed in JanuaryFebruary. This result can be explained by biomass burning sources of $\mathrm{NO}_{\mathrm{x}}$. African fires have a well known seasonality with a northern fire belt in November-February and a southern fire belt in June-October (Hao and Liu, 1994; Cooke et al., 1996). Galanter et al. (2000) have shown that more than 
$75 \%$ of the $\mathrm{NO}_{\mathrm{x}}$ at the surface near equatorial Africa is the result of biomass burning that occurs from December to February. Menaut et al. (1991) assumed that $5-15 \%$ of the Sahelian savanna (dry savanna), 25-50\% of the Sudanian savanna, and $60-80 \%$ of the Guinean savannas (wet savanna) were burned every year. Seasonal $\mathrm{NO}_{2}$ concentrations at Lamto are two times higher in the dry season $(1.4 \pm 0.4 \mathrm{ppb})$ than in the wet season $(0.7 \pm 0.2 \mathrm{ppb})$. At Djougou (Benin), concentrations in the dry season are four times higher $(2.2 \pm 0.8 \mathrm{ppb})$ than in the wet season (0.5 ppb). During the 2005-2006 enhanced observation period of the AMMA experiment, $\mathrm{NO}_{\mathrm{x}}$ measurements were made using an active analyzer (42i-TL Megatec). Between October 2005 and September 2006, mean dry season concentration $(3.2 \pm 1.6 \mathrm{ppb})$ is eight times higher than in the wet season $(0.4 \pm 0.2 \mathrm{ppb})$. These values are of the same order of magnitude and confirm measurements obtained using the IDAF passive samplers at Djougou. In the wet savanna of Lamto, Serça et al. (1998) measured low biogenic NO fluxes, ranging from $0.11 \mathrm{ng}$ NO- $\mathrm{N} \mathrm{m}^{-2} \mathrm{~s}^{-1}$ at the end of the dry season to $0.56 \mathrm{ng}$ NO-N m${ }^{-2} \mathrm{~s}^{-1}$ (mean) during the wet season. NO fluxes measured during the wet season were significantly higher $(\approx 5$ times higher) than fluxes measured during the dry season. Interestingly, the relatively high $\mathrm{NO}_{\mathrm{x}}$ concentrations encountered at Lamto (during the dry season) are not explained by the very low NO emissions from savanna soils but by remote biomass burning emissions at the regional scale (Abbadie et al., 2006). In contrast to dry savannas, monthly mean $\mathrm{NO}_{2}$ concentrations in the wet savannas are higher in the dry season (November to March). Annual mean concentrations are $1.0 \pm 0.3 \mathrm{ppb}\left(\mathrm{NO}_{2}\right)$ at Lamto and $1.2 \pm 0.1 \mathrm{ppb}$ at Djougou, with interannual variabilities of $29 \%$ and $10 \%$, respectively. The interannual variability is more representative at Lamto since 10 years of measurements are available, whilst only 3 years of observations have been obtained at Djougou. The interannual variability is largely attributable to the spatio-temporal variations of savanna fires. In 1990-1991, Ferm and Rodhe (1997) performed the first passive sampler measurements at Lamto. $\mathrm{NO}_{2}$ concentrations of $0.5 \mathrm{ppb}$ were measured in SeptemberOctober 1990 and 2 ppb in February, and are coherent with IDAF measurements. IDAF measurements tend to demonstrate that biomass burning in the dry season for wet savannas and biogenic soil $\mathrm{NO}_{\mathrm{x}}$ emissions in the wet season for the dry savannas have comparable contributions: $1.4-2.2 \mathrm{ppb}$ of $\mathrm{NO}_{2}$ for biomass burning and 2.1-3.1 ppb of $\mathrm{NO}_{2}$ for $\mathrm{NO}$ emission from soils. This result confirms the conclusion provided by Jaegle et al. $(2004,2005)$ with comparable contributions of soils and biomass burning to the $\mathrm{NO}_{\mathrm{x}}$ budget at the scale of the African continent.

In forests, monthly mean $\mathrm{NO}_{2}$ concentrations range between $0.5 \pm 0.3 \mathrm{ppb}$ to $1.5 \pm 0.5 \mathrm{ppb}$ at Zoetele (ten years of measurements) and $0.8 \pm 0.3 \mathrm{ppb}$ to $2.4 \pm 1.3 \mathrm{ppb}$ at Bomassa (eight years of measurements) (Fig. 5c). Monthly mean concentrations increase slowly during the dry season (from December to February). Seasonality is similar at the two sites with maxima registered in February-March. $\mathrm{NO}_{2}$ enhancements correspond to the biomass burning season (Cros et al., 1992; Cooke et al., 1996; Galanter et al., 2000). In the Mayombe equatorial rain forest of Congo, Serça et al. (1998) measured NO emissions from soils. NO fluxes in the wet season (4.41 ng NO-N m${ }^{-2} \mathrm{~s}^{-1}$ ) were 3 times higher than those of the dry season (1.54 ng NO-N $\mathrm{m}^{-2} \mathrm{~s}^{-1}$ ). Even if NO fluxes are high, NO is rapidly transformed into $\mathrm{NO}_{2}$, and a large part of $\mathrm{NO}_{2}$ is captured by the leafy plant density (Jacob and Bakwin, 1991; Sparks et al., 2001). In the forested ecosystems, seasonal concentrations are comparable: $1.1 \pm 0.2 \mathrm{ppb}$ and $0.9 \pm 0.3 \mathrm{ppb}$ at Zoetele and $1.6 \pm 0.5 \mathrm{ppb}$ and $1.4 \pm 0.5 \mathrm{ppb}$ at Bomassa, in the dry and wet seasons respectively. However, wet season values remain somewhat higher. These measurements tend to show that the biomass burning source during the dry season is equivalent to soil emissions buffered by canopy uptake in forests during the wet season. Mean annual concentrations are $0.9 \pm 0.2 \mathrm{ppb}$ at Zoetele and $1.4 \pm 0.4 \mathrm{ppb}$ at Bomassa, with interannual variability of $23 \%$ and $31 \%$, respectively.

As a comparison with West and Central Africa, $\mathrm{NO}_{2}$ concentrations as monitored in other tropical regions are given here as examples. At the semi-arid Indian site of Rampur, annual $\mathrm{NO}_{2}$ concentrations were found to be about $7 \mathrm{ppb}$ (Gupta et al., 2003). In South Africa, measurements from Louis Trichardt, a non-perturbed, rural, dry savanna site and Cape Point, a preserved, coastal site, present annual mean concentrations of 0.7 and $1.2 \mathrm{ppb}$, respectively. These values are close to concentrations observed in West and Central wet savannas and forests (Table 5). Levels of annual $\mathrm{NO}_{2}$ concentrations measured at Amersfoort (2.5 ppb), a South African dry savanna site influenced by industrial emissions, are comparable to those observed at West African dry savanna sites (1.8 to $2.4 \mathrm{ppb}$ ) (Martins et al., 2007). As a partial conclusion, we assume that $\mathrm{NO}_{2}$ concentrations are higher in dry savannas compared to wet savannas and forests.

\subsection{Nitric acid $\left(\mathrm{HNO}_{3}\right)$}

Monthly mean concentrations of $\mathrm{HNO}_{3}$ range between $0.1 \pm 0.1 \mathrm{ppb}$ and $1.4 \pm 0.4 \mathrm{ppb}$ in dry savannas, $0.2 \pm 0.1 \mathrm{ppb}$ and $0.7 \pm 0.3 \mathrm{ppb}$ in wet savannas and $0.1 \pm 0.1 \mathrm{ppb}$ and $0.5 \pm 0.3 \mathrm{ppb}$ in equatorial forests (Fig. $6 \mathrm{a}, \mathrm{b}, \mathrm{c}$ ). The minimum values measured are similar for all ecosystems and represent two to four times the detection limit value. The maxima present a negative gradient from the dry savannas $(1.4 \mathrm{ppb})$ to the forest $(0.5 \mathrm{ppb})$. Results show that monthly $\mathrm{HNO}_{3}$ evolution is very comparable to $\mathrm{NO}_{2}$ monthly evolution, following the same gradient. We assume that this evolution is not related to potential interference between $\mathrm{HNO}_{3}$ and $\mathrm{NO}_{2}$ passive samplers. Indeed, for the $\mathrm{NO}_{2}$ passive sampler, $\mathrm{NaOH}$ molecules react with atmospheric $\mathrm{CO}_{2}$ to form water molecules that in fact favour (or further) $\mathrm{NO}_{2}$ retention on the filter. As a result, the choice of this basic solution allows simultaneous capture of other acid gases such as 

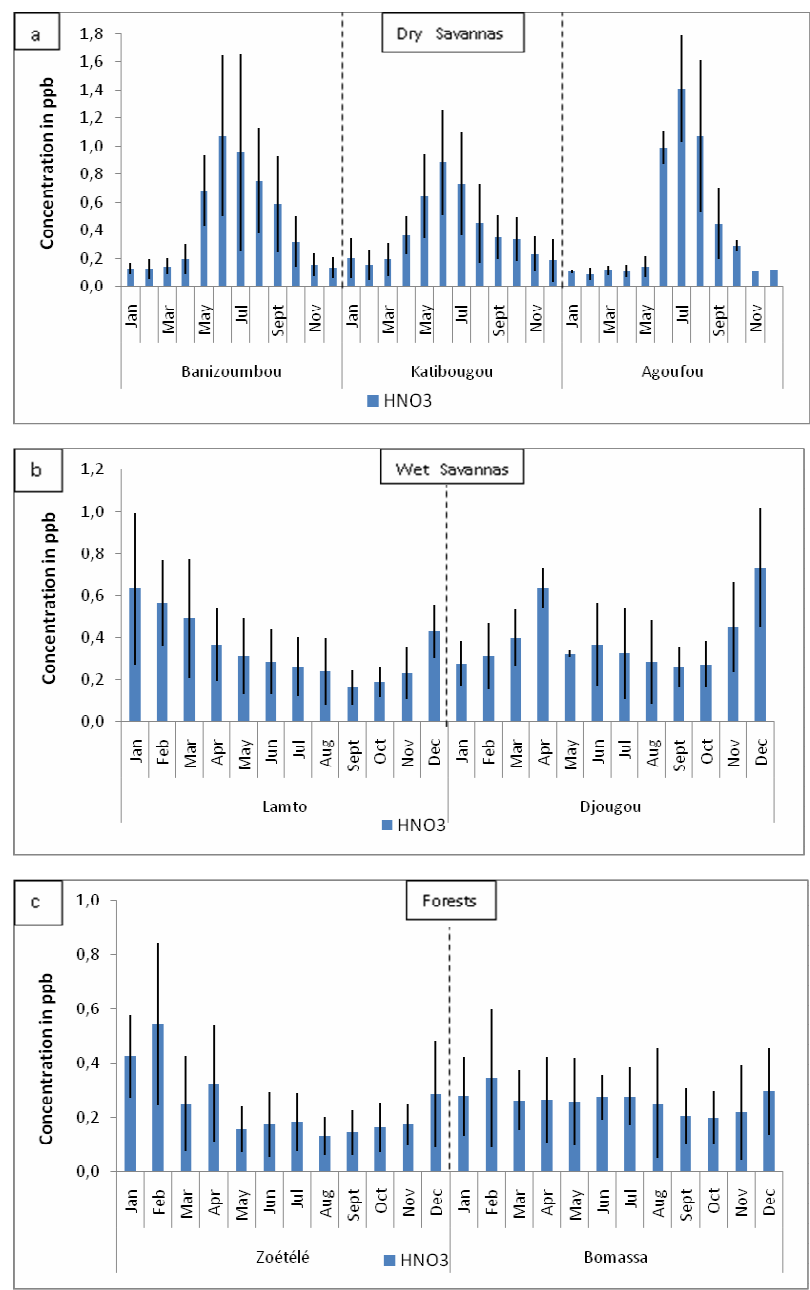

Fig. 6. Evolution of monthly $\mathrm{HNO}_{3}$ concentrations on the transect dry savannas (a), wet savannas (b), forests (c).

$\mathrm{HNO}_{3}$ on the Whatman filter. To avoid these interferences, it is important to note that the choice of sodium hydroxide as impregnation solution for the $\mathrm{NO}_{2}$ sampler aims to maintain a strongly basic $\mathrm{pH}(\mathrm{pH}>12)$, thus limiting the oxidation of nitrite ion $\mathrm{NO}_{2}^{-}$to nitrate ion $\mathrm{NO}_{3}^{-}$. Secondly, the analytical process for $\mathrm{NO}_{2}$ samplers allows the determination of nitrate in addition to nitrite ions. Our results show that nitrate concentrations are very low compared to nitrite $\mathrm{NO}_{2}^{-}$ions, with the ratio never exceeding $6 \%$. Moreover, nitrite ion concentrations are only used to determine $\mathrm{NO}_{2}$ gaseous concentrations. In the case of $\mathrm{HNO}_{3}$ filters, nitrite ions $\left(\mathrm{NO}_{2}^{-}\right)$were not detected, or at the very least, they are below the detection limit. We therefore can assume that the interferences between $\mathrm{HNO}_{3}$ and $\mathrm{NO}_{2}$ are negligible.

If we consider the seasons, mean $\mathrm{HNO}_{3}$ concentrations along the transect are $0.8 \pm 0.2 \mathrm{ppb}, 0.3 \pm 0.1 \mathrm{ppb}$ et $0.2 \pm 0.1 \mathrm{ppb}$ during the wet season and $0.2 \pm 0.1 \mathrm{ppb}$, $0.5 \pm 0.2 \mathrm{ppb}$ and $0.4 \pm 0.1 \mathrm{ppb}$ during the dry season, for dry savannas, wet savannas and forests respectively.
The highest $\mathrm{HNO}_{3}$ concentrations are measured in the wet season of the arid Sahelian ecosystems, contrary to the wet savannas and forests. These results are consistent with the measured $\mathrm{NO}_{2}$ seasonal cycle, which is maximum during the rainy season in dry ecosystems. Higher concentrations of $\mathrm{HNO}_{3}$ in the wet season can be explained by increased production of $\mathrm{HNO}_{3}$ from gaseous precursors through photochemical activity. This mechanism is particularly active in tropical regions with high humidity and temperature leading to maximum production of hydroxyl radicals $(\mathrm{OH})($ Graedel and Crutzen, 1993). For $\mathrm{NO}_{2}$, arid savannas present a second maximum during the dry season (October-November) that is not observed for $\mathrm{HNO}_{3}$. The dry season is characterized by high load of atmospheric dust particles and lower $\mathrm{NO}_{\mathrm{x}}$ precursor emissions. Thus, mineral dust captures gaseous $\mathrm{HNO}_{3}$ and neutralizes acidity with carbonates of $\mathrm{Ca}^{2+}$ or $\mathrm{Mg}^{2+}$. Carmichael et al. (1997) and Dentener et al. (1996) deduced that dust particles can significantly influence the atmospheric cycles of trace gas species such as $\mathrm{HNO}_{3}$, especially in tropical areas. In African ecosystems, heterogeneous processes leading to acidity neutralization with alkaline particles have also been clearly emphasized in the wet season to explain the low $\mathrm{pH}$ of precipitation in semi-arid savannas (Galy-Lacaux et al., 2009; Galy-Lacaux and Modi, 1998). In wet savannas and forested ecosystems, lower $\mathrm{HNO}_{3}$ concentrations are directly correlated with lower levels of measured $\mathrm{NO}_{2}$ concentrations (Serça et al., 1998; Jaegle et al., 2004), and can also be attributed to the very high $\mathrm{HNO}_{3}$ solubility in water which is thus easily scavenged by clouds and rain (Sigha et al., 2003; Yoboue et al., 2005). At a tropical forested savanna site of South America, very low concentrations of $\mathrm{HNO}_{3}(0.04 \mathrm{ppb})$ were reported by Rondon and Sanhueza (1990).

Our work estimates for the first time an order of magnitude for $\mathrm{HNO}_{3}$ concentrations representative of different ecosystems in West Africa (Table 5). Based on the 10 year period, mean annual $\mathrm{HNO}_{3}$ concentrations are $0.5 \pm 0.2 \mathrm{ppb}$ in dry savannas and $0.3 \pm 0.1 \mathrm{ppb}$ in wet savannas and forests.

Measurements of ambient $\mathrm{HNO}_{3}$ levels are few, especially in tropical areas. An original paper from Ferm et al. (2005) related to corrosion studies presents nitric acid measurements from two years of measurement using diffusive samplers at 11 rural and 23 urban sites in northern Europe. High values are measured in Milan, Athens and London with annual average results varying from 0.16 to $2.5 \mu \mathrm{g} / \mathrm{m}^{3}$ (0.05 to $1 \mathrm{ppb}$ ). In rural northern European sites, monthly $\mathrm{HNO}_{3}$ concentrations range between 0 and $0.5 \mu \mathrm{g} / \mathrm{m}^{3}$ (0 to $0.2 \mathrm{ppb}$ ). In the tropics, a project of corrosion studied in the frame of the RAPIDC program (http://www.sei.se/rapide/ pdfs/corrsion.PDF) reports $\mathrm{HNO}_{3}$ concentrations from 14 stations of Africa and Asia in tropical and sub-tropical areas. The average $\mathrm{HNO}_{3}$ concentrations show a rather uniform distribution, with monthly mean concentrations between 0.4 and $0.6 \mathrm{ppb}$ (Tidblad et al., 2007). The study also reports annual $\mathrm{HNO}_{3}$ concentrations varying from $0.1 \mathrm{ppb}$ at Mytho (Ho 
Chi Minh Branch of the Environmental Institute of Materials science) to $1.5 \mathrm{ppb}$ at Kuala Lumpur (Malaysia). Gupta et al. (2003) present $\mathrm{HNO}_{3}$ measurements at an Indian rural site (Rampur) with an annual mean of $0.3 \mathrm{ppb}$. This level is quite comparable to $\mathrm{HNO}_{3}$ concentrations obtained for African ecosystems in this work. Concentrations are around $0.5 \mathrm{ppb}$, with a maximum at Amersfoort (South Africa, industrialized dry savanna) of $0.9 \mathrm{ppb}$ and a minimum of $0.2 \mathrm{ppb}$ in the remote South African site of Louis Trischardt and at Zoetele (forest in Cameroon).

\subsection{Ozone $\left(\mathrm{O}_{3}\right)$}

Monthly mean ozone surface concentrations range between $4.4 \pm 0.5 \mathrm{ppb}$ and $21 \pm 4.5 \mathrm{ppb}$ in dry savannas, between $6.9 \pm 1.0 \mathrm{ppb}$ and $17.3 \pm 5.0 \mathrm{ppb}$ in wet savannas and between $2.8 \pm 0.8 \mathrm{ppb}$ and $7.3 \pm 1.7 \mathrm{ppb}$ in forested ecosystems (Fig. 7a, b, c). Along the ecosystem transect, the seasonal trend in ozone is comparable to $\mathrm{NO}_{2}$ seasonal evolution. In dry savannas, mean seasonal concentrations in the wet season (16.8 $\pm 5.2 \mathrm{ppb}$ at Banizoumbou, $14.8 \pm 3.9 \mathrm{ppb}$ at Katibougou and 16.4 $\pm 4.8 \mathrm{ppb}$ at Agoufou) are twice as high in the dry season (7.9 $\pm 1.9 \mathrm{ppb}$ at Banizoumbou, $10.2 \pm 1.7 \mathrm{ppb}$ at Katibougou and $7.4 \pm 1.6 \mathrm{ppb}$ at Agoufou). In wet savannas, mean concentrations in the dry season $(13.2 \pm 2.5 \mathrm{ppb}$ at Lamto and $16.5 \pm 5.0$ at Djougou) are comparable to dry savannas in the wet season. In the wet season, ozone concentrations observed at Lamto and Djougou are 9.1 $1.1 \mathrm{ppb}$ and $12.8 \pm 3.0 \mathrm{ppb}$, respectively. At the two forested sites, there is little or no seasonal difference in ozone concentrations. For the Congolese forest of Bomassa, concentrations are $4.0 \pm 0.8 \mathrm{ppb}$ and $4.0 \pm 0.4 \mathrm{ppb}$ in the wet and dry seasons, respectively. For Zoetele in Cameroon, we measure $7.2 \pm 1.1 \mathrm{ppb}$ in the dry season and $4.1 \pm 0.9 \mathrm{ppb}$ in the wet season. Annual mean concentrations are around 11-14 ppb in dry and wet savannas $(11.9 \pm 2.3 \mathrm{ppb}$ at Banizoumbou, $12.6 \pm 2.2 \mathrm{ppb}$ at Katibougou and $12.2 \pm 2.6 \mathrm{ppb}$ at Agoufou, $10.9 \pm 1.8 \mathrm{ppb}$ at Lamto and $14.0 \pm 2.8 \mathrm{ppb}$ in Djougou) and $4-5 \mathrm{ppb}$ in forests $(4.8 \pm 1.0 \mathrm{ppb}$ at Zoetele and $4.0 \pm 0.4 \mathrm{ppb}$ at Bomassa). The interannual variability is about $10 \%$ at Bomassa, 21\% at Zoetele and Agoufou, 19\% at Banizoumbou, $17 \%$ at Katibougou, $16 \%$ at Lamto and $20 \%$ at Djougou. Spatio-temporal evolution of ozone concentration distributions depends on various processes, since ozone production is non-linearly driven by the supply of nitrogen oxides and VOC from biomass burning, fossil fuel combustion, biogenic sources and soils (Jacob et al., 1990, 1991, 1995). In the tropics, in the absence of anthropogenic biomass burning, the seasonal variation of $\mathrm{O}_{3}$ in the boundary layer is mainly a consequence of photochemical processes and the exchange between the free troposphere and terrestrial surfaces.

In the semi arid savannas the seasonal cycle is clear, with a maximum in June-July, the heart of the wet season. This is the result of active photochemical production of ozone in the boundary layer associated with high $\mathrm{NO}_{\mathrm{x}}$ concentra-
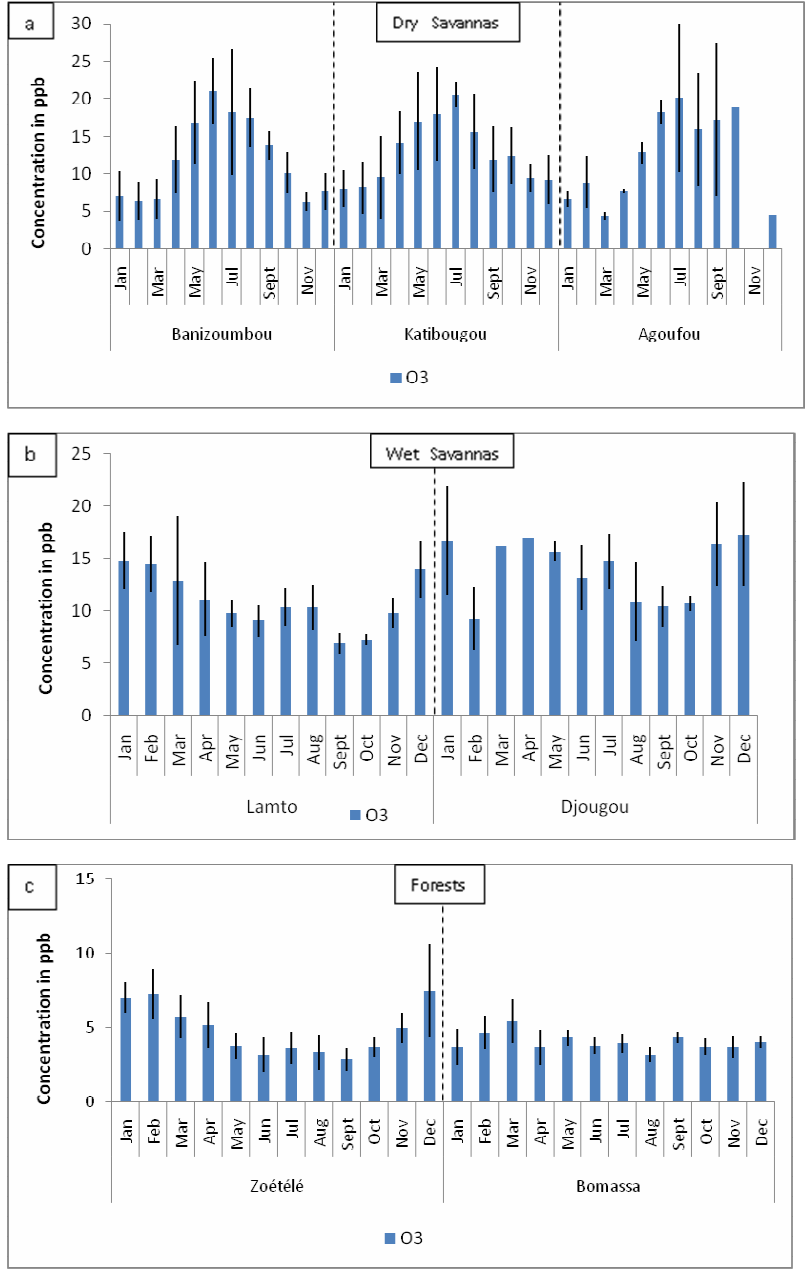

Fig. 7. Evolution of monthly $\mathrm{O}_{3}$ concentrations on the transect dry savannas (a), wet savannas (b), forests (c).

tions. During the AMMA experiment wet season Stewart et al. (2008) estimated production of ozone in the Sahel at a rate of $1 \mathrm{ppbh}^{-1}$, the result of high $\mathrm{NO}_{\mathrm{x}}$ concentrations in the boundary layer. Moreover, the measurements of $\mathrm{NO}_{\mathrm{x}}$ and ozone concentrations during the low level transects of the AMMA flights present a good correlation. The same correlation is found in IDAF measurements. The Sahelian region is an original case in atmospheric chemistry where ozone production is mainly related to natural biogenic precursor sources. IDAF gas concentrations confirm this result.

In the wet savannas of Lamto, $\mathrm{NO}_{\mathrm{x}}$ is well correlated to $\mathrm{O}_{3}$ concentrations $\left(R^{2}=0.7\right)$. Lamto is strongly influenced by biomass burning from West and Central Africa from December to February (Lacaux et al., 1995), but is far enough from anthropogenic sources of emissions that ozone production is driven by a $\mathrm{NO}_{\mathrm{x}}$-limited regime. At Lamto (wet savanna), fires generally occur in January, i.e., in the heart of the dry season and around $80 \%$ of the savanna soil surface 
is burned annually (Abbadie et al., 2006). Biomass burning thus likely significantly contributes to ozone production through the emissions of precursors $\left(\mathrm{NO}_{\mathrm{x}}\right.$ and $\left.\mathrm{CO}\right)$. Indeed, Liu et al. (1987) have shown higher ozone production efficiency for lower $\mathrm{NO}_{\mathrm{x}}$ mixing ratios at rural stations. Similarly, Galanter et al. (2000) have shown that from December to February, biomass burning contributes indirectly to 30 to $40 \%$ to the $\mathrm{O}_{3}$ concentration over equatorial and northern Africa at $940 \mathrm{hPa}$.

For African forested ecosystems, ozone concentrations are lower. The mean annual concentrations are around $4 \mathrm{ppb}$. This result is consistent with measurements by Cros et al. (1987) in the Mayombe forest of Congo. Under the canopy at an altitude of $3 \mathrm{~m}$, the $\mathrm{O}_{3}$ levels were observed to be continuously very low, never above $5 \mathrm{ppb}$. At the two forested sites the observed maximum in ozone concentrations occurs during the biomass burning season in this ecosystems, consistent with the observations of Cros et al. (1992). Several studies have shown that tropical forests appear to be a major $\mathrm{O}_{3}$ sink, through ground and foliage deposits and loss through chemical reactions with hydrocarbons and nitrogen oxides (Rummel at al., 2007; Jacob and Wofsy, 1990; Bakwin et al., 1990; Kaplan et al., 1988). Hence, in forests, all strata of the vegetation may participate in the destruction of ozone by dry deposition and chemical reactions (Cros et al., 1992). Mean ozone deposition velocites have been measured to be very high in northern Congo (Cros et al., 1992; Andreae et al., 1992) and in the Republic of Central Africa (Cros et al., 2000). Saunois et al. (2009) have shown from measurements of the FAAM BAe-146 aircraft that there is a strong ozone gradient between forest and bare soil in the boundary layer in West Africa. They observed an increase of ozone mixing ratios from $25 \mathrm{ppbv}$ over the forested area up to $40 \mathrm{ppbv}$ over the Sahelian area in the West African lower troposphere. They also found that the lower values of ozone over vegetation are essentially controlled by dry deposition over trees and that the ozone maximum is clearly a consequence of higher $\mathrm{NO}_{\mathrm{x}}$ mixing ratios north of $12^{\circ} \mathrm{N}$. IDAF surface measurements tend to confirm this strong ozone gradient between forests (seasonal mean concentration around $4 \mathrm{ppb}$ ) and dry savannas (around $16 \mathrm{ppb}$ ) in the wet season. Measurements have also been performed in the Amazonian forest of French Guyana (Petit Saut Site) where ozone observations indicate low concentrations with an annual mean of $4.6 \pm 0.7 \mathrm{ppb}$ (from 2001-2007) (C. GalyLacaux, personal communication, 2009).

Few observational studies of surface $\mathrm{O}_{3}$ are available over tropical areas. In the Indian region, Naja and Lal (2002) reported monthly average $\mathrm{O}_{3}$ concentrations ranging from $18.1 \pm 10.8 \mathrm{ppbv}$ (October) to $33.6 \pm 20.6 \mathrm{ppb}$ (March) at the rural site of Gadanki $\left(13.5^{\circ} \mathrm{N}, 79.2^{\circ} \mathrm{E}\right)$ during the period 1993 to 1996. Also, in a tropical, rural coastal site of Southeast India, from May 1997 to October 2000, Debaje et al. (2003) reported average $\mathrm{O}_{3}$ concentrations from $17 \pm 7 \mathrm{ppbv}$ (October) to $23 \pm 9 \mathrm{ppbv}$ (May) at Tranquebar $\left(11^{\circ} \mathrm{N}, 79.9^{\circ} \mathrm{E}\right)$. The increase in $\mathrm{O}_{3}$ was attributed to the increase in $\mathrm{NO}_{\mathrm{x}}$ and other precursor emissions from different sources in the proximity of this site. The monthly average $\mathrm{O}_{3}$ concentrations at the Indian rural sites are higher than those reported at African rural sites $(2.8 \pm 0.8 \mathrm{ppb}$ to $21 \pm 4.5 \mathrm{ppb}$ on the transect of ecosystems). Annual mean ozone concentrations in South Africa ( $27 \pm 8.3 \mathrm{ppb}$ at Amersfoort and Cape Point, $35 \pm 8.6 \mathrm{ppb}$ at Louis Trichardt) are two and a half times higher than those measured in Western and Central African dry and wet savannas (12 ppb) and forests (4 ppb). This is the result of industrial pollution, which directly affects all the South African sites because of air mass recirculation. Higher ozone levels in the remote dry savanna of Louis Trischardt is probably also due to a large intercontinental mixing zone of ozone precursor gases (namely: volatile organic compounds from biomass burning in Zambia and Zimbabwe and $\mathrm{NO}_{2}$ from the industrial activities in South Africa) (Martins et al., 2007).

\subsection{Ammonia $\left(\mathrm{NH}_{3}\right)$}

Monthly mean $\mathrm{NH}_{3}$ concentrations range from $3.2 \pm 1.6 \mathrm{ppb}$ to $10.6 \pm 1.8 \mathrm{ppb}$ in dry savannas; from $2.0 \pm 0.2 \mathrm{ppb}$ to $8.4 \pm 1.9 \mathrm{ppb}$ in wet savannas and from $2.9 \pm 1.0 \mathrm{ppb}$ to $7.2 \pm 4.3 \mathrm{ppb}$ in the forests (Fig. 8a, b, c). In dry savannas, mean concentrations in the wet season are: $7.7 \pm 2.5 \mathrm{ppb}$ at Banizoumbou, $8.1 \pm 1.9 \mathrm{ppb}$ at Katibougou and $8.4 \pm 1.2 \mathrm{ppb}$ at Agoufou. In the dry season lower concentrations are measured: $5.3 \pm 1.6 \mathrm{ppb}$ at Banizoumbou, $5.5 \pm 1.1 \mathrm{ppb}$ at Katibougou and $5.7 \pm 0.5 \mathrm{ppb}$ at Agoufou. In wet savannas, the phenomenom is inversed, i.e. we measured lower mean concentrations in the wet season $(3.0 \pm 1.0 \mathrm{ppb}$ at Lamto and $3.1 \pm 1.3 \mathrm{ppb}$ at Djougou) and higher mean concentrations in the dry season (5.2 $\pm 1.5 \mathrm{ppb}$ at Lamto and Djougou). In the forests, no significant difference between wet and dry season exists. Concentrations are $4.1 \pm 1.0 \mathrm{ppb}$ and $4.4 \pm 1.4 \mathrm{ppb}$ at Zoetele and $4.6 \pm 1.6 \mathrm{ppb}$ and $5.1 \pm 2.2 \mathrm{ppb}$ at Bomassa, in the wet and the dry seasons, respectively. Annual mean concentrations of ammonia in the dry savannas are $6.3 \pm 2.0 \mathrm{ppb}$ at Banizoumbou, $6.6 \pm 1.0 \mathrm{ppb}$ at Katibougou and $7.4 \pm 0.8 \mathrm{ppb}$ at Agoufou (Table 5) (with interannual variability of $31 \%$, $15 \%$ and $10 \%$ respectively). These values are higher than those measured in the other ecosystems: $4.0 \pm 1.2 \mathrm{ppb}$ at Lamto, 3.9 $\pm 1.4 \mathrm{ppb}$ at Djougou, $4.2 \pm 0.9 \mathrm{ppb}$ at Zoetele and $4.7 \pm 1.7 \mathrm{ppb}$ at Bomassa (Table 5). The interannual variability over the ten years is about $29 \%, 22 \%$ and $35 \%$ for Lamto, Zoetele and Bomassa, respectively, and 35\% for Djougou over the three years of observations. No specific trend in variability is observed. It is noticeable that wet savannas and forests present seasonal and mean annual $\mathrm{NH}_{3}$ concentrations of the same order of magnitude. From January to March (dry season), monthly atmospheric concentrations of $\mathrm{NH}_{3}$ in wet savannas and forests are higher than $4 \mathrm{ppb}(5-8 \mathrm{ppb})$. Over the same period, $\mathrm{NH}_{3}$ concentrations are lower in dry savannas and around $4 \mathrm{ppb}$. Then, from May to the end of the 

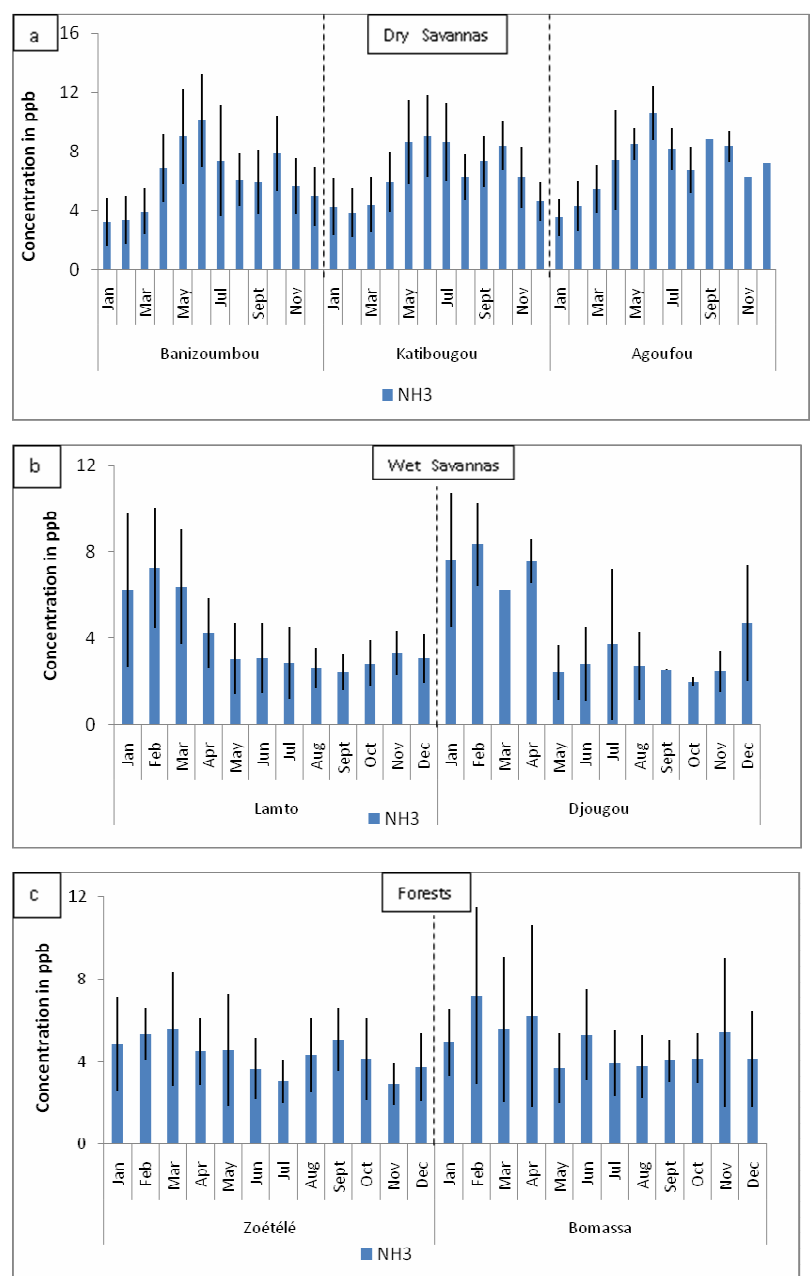

Fig. 8. Evolution of monthly $\mathrm{NH}_{3}$ concentrations on the transect dry savannas (a), wet savannas (b), forests (c).

wet season, we observed high $\mathrm{NH}_{3}$ concentrations in dry savannas from 5 to $10 \mathrm{ppb}$. In 1990-1991, $\mathrm{NH}_{3}$ concentrations at Lamto were also measured by Ferm and Rodhe (1997). $\mathrm{NH}_{3}$ concentrations of 2-3 ppb were observed in SeptemberOctober 1990 and 5-7 ppb in January-February, and are coherent with IDAF measurements.

Major sources of $\mathrm{NH}_{3}$ include bacterial decomposition of urea in animal excreta and emission from natural or fertilized soils (Schlesinger and Hartley, 1992; Bouwman et al., 2002). In tropical regions, another significant source of ammonia is savanna fires and domestic fuelwood burning (Lobert et al., 1990; Delmas et al., 1995; Brocard et al., 1996). For the remote sites of the IDAF network, neither industrial nitrogen sources nor nitrogenous emissions from synthetic fertilization need to be considered. In wet savannas and forests, the $\mathrm{NH}_{3}$ concentrations represent a combination of all natural sources with the largest contribution from biomass burning sources, as shown by the highest concentration observed in the dry season. In a rural site of the Amazon basin, Trebs et al. (2004) measured a mixing ratio of $\mathrm{NH}_{3}$ of $8 \mathrm{ppb}$ in the burning season, 3 times higher than in the wet season. This result is quite comparable to concentrations recorded in the dry season of the West and Central African wet savannas and forests. During the wet season in the Sahelian region the burning of savanna is improbable and the main source of ammonia is likely the hydrolysis of urea from animal urine deposited in grazing areas. High densities of domestic animals are concentrated on the fresh natural pastures which green during the rainy season. McCalley et al. (2008) measured $\mathrm{NO}$ and $\mathrm{NH}_{3}$ emission from the desertic Mojave soils. Results indicate that seasonal changes in temperature and precipitation drive emissions, with maximum fluxes in the wet season around 0.9 to $10 \mathrm{ng} \mathrm{N} \mathrm{m}^{-2} \mathrm{~s}^{-1}$ (from 0.3 to $3 \mathrm{~kg} \mathrm{Nha}^{-1} \mathrm{yr}^{-1}$ ). In Niger, Modi et al. (1995) estimated $\mathrm{NH}_{3}$ emission to be $0.5 \mathrm{~kg} \mathrm{ha}^{-1} \mathrm{yr}^{-1}$, representing a flux of $3.1 \mathrm{mmol} \mathrm{m}^{-2} \mathrm{yr}^{-1}$. Ammonium wet deposition of $6.3 \mathrm{mmole} \mathrm{m}^{-2} \mathrm{yr}^{-1}$ in 1996 at Banizoumbou confirms the intense source of ammonia in this semi-arid savanna (GalyLacaux and Modi, 1998). Atmospheric ammonia fluxes have been estimated in the Sahel and more generally in Africa (Schlecht et al., 1998; Bouwman et al., 2002). In the Sahelian zone, agro-pastoralism appears to be very important, representing 25 to $30 \%$ of the GDP (Gross Production Product). Pastoralism contributes to 10 to $15 \%$ of the GDP of Mali and Niger for example. It is important to note that the pastoralism is mainly nomadic in nature. Recently, Delon et al. (2010) developed a specific $\mathrm{NH}_{3}$ emission inventory for 23 countries of West Africa where grazing, related to the number of head of cattle, seems to be the most important source of $\mathrm{NH}_{3}$. The quantity of nitrogen released by livestock is calculated from Schlecht et al. (1998), in $\mathrm{gN} \mathrm{head}^{-1} \mathrm{day}^{-1}$, for cows, sheep and goats. This estimate is multiplied by the number of animals per $\mathrm{km}^{2}$ in each region of each country concerned using information from the FAO (Food and Agriculture Organization) GLiPHA (Global Livestock Production and Health Atlas) database. The mean total nitrogen input from animal manure is estimated to be $23 \mathrm{kgN} \mathrm{ha}^{-1} \mathrm{yr}^{-1}$ at Agoufou, $25 \mathrm{kgNha}^{-1} \mathrm{yr}^{-1}$ at Banizoumbou and $11 \mathrm{kgN} \mathrm{ha}^{-1} \mathrm{yr}^{-1}$ at Katibougou. Conditions in the Sahel regions favor $\mathrm{NH}_{3}$ volatilization, i.e. high temperatures, low soil moisture and bare soil surfaces. As a consequence, a loss rate of 30 to $50 \%$ has been applied to the input of nitrogen by animal manure previously calculated. This leads to $\mathrm{N}-\mathrm{NH}_{3}$ volatilization estimates ranging from 3 to $6 \mathrm{kgN} \mathrm{ha}^{-1} \mathrm{yr}^{-1}$ at Katibougou, and from 7 to $12 \mathrm{kgN} \mathrm{ha}^{-1} \mathrm{yr}^{-1}$ at Agoufou and Banizoumbou, depending on the loss rate. The rest of the nitrogen input remains in the soil and is further used for the release of biogenic NO.

In order to produce a rough estimation of the comparison between emission fluxes and surface concentrations, (without taking into account the compensation point of $\mathrm{NH}_{3}$ ) we assume that all $\mathrm{NH}_{3}$ emitted in arid regions is returned to the surface by deposition (wet and dry) (Bouwman et al., 2002) and we use the relation between deposition flux and concentration defined by Eq. (4): 
$C_{\mathrm{Z}}=C_{\mathrm{z}}=F / V_{\mathrm{d}}$

where $F$ is the deposition flux of the trace gas (molecules $\left.\mathrm{m}^{-2} \mathrm{~s}^{-1}\right), V_{\mathrm{d}}$ is the deposition velocity $\left(\mathrm{m} \mathrm{s}^{-1}\right)$, $C_{\mathrm{Z}}$ is the concentration of the gas (molecules $\mathrm{m}^{-3}$ ) at reference height $z$. The concentration $C_{\mathrm{z}}$ is converted to ppb afterwards. Using a dry deposition velocity of around $0.4 \mathrm{~cm} \mathrm{~s}^{-1}$ (Trebs et al., 2006; Zhang et al., 2003), and a 30\% loss rate of nitrogen $(\mathrm{N})$ input, mean $\mathrm{NH}_{3}$ calculated concentrations are $8.9 \mathrm{ppb}$ at Agoufou and Banizoumbou. These values are comparable to those obtained with IDAF passive samplers (7.4 ppb at Agoufou and 6.3 ppb at Banizoumbou) and we assume that animals represent the main $\mathrm{NH}_{3}$ source for these arid and semi-arid ecosystems. These concentrations are five times higher than in South Africa $(1.2 \pm 0.7 \mathrm{ppb}$ at Amersfoort and Louis Trichardt, $1.5 \pm 0.7 \mathrm{ppb}$ at Cape Point) (Table 5). Mean annual concentrations also remain high in wet savannas and forests (around 4 ppb). Carmichael et al. (2003) noticed that ambient ammonia levels are high in the Indian sub continent, Southeast and South Asia and Africa. These concentrations reflect the high $\mathrm{NH}_{3}$ emission from agricultural activities, livestock and the use of biofuels (animal dung) as domestic fuel.

\subsection{Sulfur dioxide $\left(\mathrm{SO}_{2}\right)$}

In general, we measure low $\mathrm{SO}_{2}$ concentrations at all West and Central African sites. This result is also true for all southern African sites except Amersfoort (Table 5). For the West and Central African sites, the annual mean $\mathrm{SO}_{2}$ concentrations are of the same order of magnitude in dry savannas $(0.6 \pm 0.2 \mathrm{ppb}$ at Banizoumbou and Katibougou, $1.0 \pm 0.2 \mathrm{ppb}$ at Agoufou) and wet savannas $(0.5 \pm 0.2 \mathrm{ppb}$ at Lamto and $0.8 \pm 0.3 \mathrm{ppb}$ at Djougou). For forested ecosystems, annual mean $\mathrm{SO}_{2}$ concentrations are two times lower $(0.3 \pm 0.1 \mathrm{ppb}$ at Zoetele and $0.4 \pm 0.2 \mathrm{ppb}$ at Bomassa). The high annual mean $\mathrm{SO}_{2}$ concentration measured at Amersfoort $(2.8 \pm 1.1 \mathrm{ppb})$ is related to the fact that for most of the time this site lies downwind of major industrial activities (Martins et al., 2007).

If we consider the seasons, mean $\mathrm{SO}_{2}$ concentrations on the transect are $0.9 \pm 0.3 \mathrm{ppb}, 0.6 \pm 0.2 \mathrm{ppb}$ and $0.3 \pm 0.2 \mathrm{ppb}$ in the wet season and $0.6 \pm 0.2 \mathrm{ppb}$, $0.7 \pm 0.4 \mathrm{ppb}, 0.4 \pm 0.2 \mathrm{ppb}$ in the dry season, for dry savannas, wet savannas and forests, respectively. We observe the same order of magnitude of $\mathrm{SO}_{2}$ in dry and wet seasons in each ecosystem with a higher value in wet season for dry savannas. This suggests a contribution of soil emission and biomass burning sources. Although soils have long been recognized as $\mathrm{SO}_{2}$ sink (Garland, 1977), it has been suggested that acid sulfate soils may in fact emit $\mathrm{SO}_{2}$ (Van Breemen, $1982,1993) . \mathrm{SO}_{2}$ can also be generated through reactions involving dissolved sulfite $\left(\mathrm{SO}_{3}^{2-}\right)$ (Barnett and Davis, 1983), which occurs naturally in soils. Macdonald et al. (2004) have shown that partially oxidized sulfide-containing acid sulfate soils are a source of atmospheric $\mathrm{SO}_{2}$ and the evolution of $\mathrm{SO}_{2}$ appears to be linked to surface soil evaporation. Moreover, biomass burning (burning of forest, grassland, and agricultural wastes) is a significant source of $\mathrm{SO}_{2}$ to the atmosphere (Bates et al., 1992; Arndt et al., 1997). However, the sulphur content of vegetation is lower compared to carbon and nitrogen elements and $\mathrm{SO}_{2}$ emissions factors for combustion process are lower than for those for carbonaceous or nitrogenous species (Lacaux et al., 1995).

$\mathrm{SO}_{2}$ and ammonia play important roles in aerosol processes, as well as through influencing the acidity of precipitation. It is interesting to note that the $\mathrm{NH}_{3} / \mathrm{SO}_{2}$ mixing ratio exceeds 10 at forested ecosystems (14 at Zoetele, 12 at Bomassa) and dry savannas (11 at Banizoumbou and Katibougou) except Agoufou (7). A ratio of 8 and 5 is observed at Lamto and Djougou, respectively (wet savannas). These results are consistent with those reported by Carmichael et al. (2003) for 24 remote sites world wide, at which the ratio at 15 sites exceeded 10 and a ratio $<1$ was not observed at any of the sites. For the Southern African sites, we note that a rather low $\mathrm{NH}_{3} / \mathrm{SO}_{2}$ mixing ratio of 1.46 and 2.73 is observed at Louis Trichardt and Cape Point, respectively, while a ratio of 0.42 is observed at Amersfoort (Martins et al., 2007).

\section{Conclusions}

The present study reports, for the first time, measurements of gaseous $\mathrm{NO}_{2}, \mathrm{HNO}_{3}, \mathrm{NH}_{3}, \mathrm{O}_{3}$, and $\mathrm{SO}_{2}$ at seven remote sites in West and Central Africa within the framework of the IDAF network. The sites are located to represent a transect of the African ecosystems, i.e., dry savanna-wet savanna-forest. Monthly measurements were obtained using a set of IDAF passive samplers over a ten year period from 1998 to 2007. The validation and inter-comparison studies conducted with the IDAF passive samplers, presented in Sect. 2, assure the quality and accuracy of these measurements. The IDAF database of gases is available at: http://medias.obs-mip.fr/idaf/. The reproducibility of IDAF passive samplers was found to be $9.8 \%, 20 \%, 14.3 \%, 10 \%$ and $16.6 \%$ for $\mathrm{NO}_{2}, \mathrm{HNO}_{3}, \mathrm{NH}_{3}, \mathrm{O}_{3}$, and $\mathrm{SO}_{2}$, respectively. For each type of African ecosystem, we studied the long term time series (1) to characterize the levels of gaseous surface concentrations, (2) to document the seasonal cycles according to the atmospheric sources of gases. We also compared West and Central African gas concentrations with results obtained from other parts of the world such as South Africa, Asia and India. We found that for all the gases measured, the seasonal concentrations were highest in the dry savannas during the wet season. Conversely, concentrations were highest in the wet savannas during the dry season. In forests, no significant difference between wet and dry seasons was observed. Along the transect of ecosystems, $\mathrm{NO}_{2}$ variability emphasizes the importance of two main $\mathrm{NO}_{\mathrm{x}}$ sources, i.e., 
biomass burning and biogenic soil emissions. IDAF measurements tend to demonstrate that biomass burning in the dry season in the wet savanna and forested ecosystems lead to $\mathrm{NO}_{2}$ concentrations of 1.1 to $2.2 \mathrm{ppb}$. These concentrations are of the same order of magnitude as those of soil biogenic $\mathrm{NO}_{\mathrm{x}}$ sources in the wet season in the arid and semi-arid savannas (2.1 to $3.1 \mathrm{ppb}$ of $\mathrm{NO}_{2}$ ). Monthly $\mathrm{HNO}_{3}$ evolution is comparable to $\mathrm{NO}_{2}$ monthly evolution, and thus follows the same gradient. Higher concentrations of $\mathrm{HNO}_{3}$ in the dry savannas during the wet season $(0.5-1 \mathrm{ppb})$ can be explained by increased production of $\mathrm{HNO}_{3}$ from gaseous precursors $\left(\mathrm{NO}_{\mathrm{x}}\right)$ during photochemical activity. IDAF measurements emphasize that $\mathrm{O}_{3}$ concentrations in the dry savannas during the wet season vary from $14.8 \pm 3.9$ to $16.8 \pm 5.2 \mathrm{ppb}$, and are of the same order of magnitude as those observed in the wet savannas during the dry season, which range from 13.2 2.5 to $16.5 \pm 5.0 \mathrm{ppb}$. The clear seasonality measured with IDAF passive samplers in the semi-arid savannas allows us to argue in favor of ozone production related to $\mathrm{NO}_{\mathrm{x}}$. Biogenic emissions likely is the main contributor to ozone production, through the emission of $\mathrm{NO}_{\mathrm{x}}$ as precursors during the wet season in the dry savanna region and biomass burning during the dry season in the wet savanna region. In forested ecosystems, the lower $\mathrm{O}_{3}$ concentrations measured in both dry and wet seasons (4-7 ppb) indicate that tropical forests appear to be a major $\mathrm{O}_{3}$ sink. For $\mathrm{NH}_{3}$, the higher concentrations measured in the wet season over semi-arid savannas (7.5-8.5 ppb) is mainly related to the hydrolysis of urea from animal excreta deposited in grazing areas. It is noticeable that the transect of ecosystems present a comparable seasonal mean $\mathrm{NH}_{3}$ concentration around $5 \mathrm{ppb}$ in the dry season. The annual mean concentrations of $\mathrm{NH}_{3}, \mathrm{NO}_{2}, \mathrm{HNO}_{3}$ measured in dry savannas are higher than those measured in wet savannas and forests, both of which have quite similar concentrations. $\mathrm{NH}_{3}$ concentrations are around 6-7.5 ppb in dry savannas and $4-5 \mathrm{ppb}$ in wet savannas and forests. Annual $\mathrm{NO}_{2}$ concentrations are around $2-2.5$ ppb in dry savannas and $1 \mathrm{ppb}$ in wet savannas and forests, whilst $\mathrm{HNO}_{3}$ concentrations are around $0.5 \mathrm{ppb}$ in dry savannas and $0.3 \mathrm{ppb}$ in wet savannas and forests. Annual $\mathrm{O}_{3}$ and $\mathrm{SO}_{2}$ concentrations are low for all the African ecosystems studied. Annual mean $\mathrm{O}_{3}$ concentrations are around $11-14 \mathrm{ppb}$ in dry and wet savannas and 4-5 ppb in forests and $\mathrm{SO}_{2}$ around $0.5-1 \mathrm{ppb}$ in dry and wet savannas and $0.3 \mathrm{ppb}$ in forests.

Results from this study have demonstrated that passive samplers are appropriate for measurements at remote sites. The low cost associated with these measurements means that good quality data covering large regions of the world can easily be obtained. The IDAF remote sites are not yet impacted by anthropogenic sources of gases and particles. However, industrial and traffic pollution is rapidly increasing in African cities. Moreover, according to the United Nations, the present urban population of 3.2 billion is likely to rise to almost 5 billion in 2030. This increase will result in dramatic consequences in developing countries. This is particularly true for West Africa where the rapid development of megacities (e.g. Lagos, Accra, Abidjan, Bamako ...) has occurred. Concerning effects on atmospheric chemistry, this signifies an inordinate surge in particle and gas emissions, with large impacts on population health as well as climatic impacts on the local and regional scale. These impacts remain unknown. To begin to study the pollution of future African megacities, we have launched the POLCA pilot program (POLlution des Capitales Africaines), during which we performed gas concentration measurements in eight African capitals during the 2004 dry season. The preliminary results reveal that the atmospheric concentrations of $\mathrm{SO}_{2}, \mathrm{NO}_{2}, \mathrm{HNO}_{3}, \mathrm{NH}_{3}$ and $\mathrm{O}_{3}$ are very high and comparable to those measured in industrialised countries of the Northern Hemisphere. An example is given by the observation of $\mathrm{NO}_{2}$ concentrations reaching $50 \mathrm{ppb}$ in Bamako, Abidjan and Dakar (V. Yoboue, personal communication, 2005). Finally, to extend the results presented in this paper, we proposed a new IDAF scientific plan for 2010, to include gaseous and particulate pollution measurements in two African capitals, Yaounde and Bamako, in order to make comparisons with the present remote sites.

Acknowledgements. This work is part of the IDAF (IGAC/DEBITS/AFRICA) project; and was funded by INSU/CNRS "Institut National des Sciences de l'Univers/Centre National de Recherche Scientifique" and the API "African Monsoon Multidisciplinary Analyses" (AMMA in 2005). Based upon a French initiative, AMMA now supported by an international scientific group is currently funded by a large number of agencies, especially from France, the United Kingdom, the United States, and Africa. It has been the beneficiary of a major financial contribution from the European Community's Sixth Framework Research Programme (FP6), see http://www.amma-international.org. The authors are grateful to all the field technicians of the IDAF network: Alfari Zakou for Banizoumbou in Niger, Raphael Zouzou for Lamto in Cote d'Ivoire, Mathieu Zang for Zoetele in Cameroon, Hama Maïga for Agoufou in Mali, Celestin Darakpa for Djougou in Benin and Kanoute Cheick for Katibougou in Mali.

Edited by: C. Reeves

\section{References}

Abbadie, L., Gignoux, J., Le Roux, X., and Lepage, M.: Lamto: Structure, Functioning, and Dynamics of a Savanna Ecosystem, Ecological Studies, 179, 415 pp., 2006.

Al-Ourabi, H.: Etude expérimentale de gaz azotés, du dioxyde de soufre et de l'ozone à l'échelle des écosystèmes de l'Afrique tropicale: Application à l'estimation des dépôts secs gazeux dans le cadre du réseau IDAF, PhD, Université Paul Sabatier-Toulouse III, 2002.

Andreae, M. O., Chapuis, A., Cros, B., Fontan, J., Helas, G., Justice, C., Kaufman, Y. J., Minga, A., and Nganga, D.: Ozone and Aitken nuclei over Equatorial Africa: Airborne observations during DECAFE 88, J. Geophys. Res., 97, 6137-6148, 1992. 
Arndt, R., Carmichael, G. R., Streets, D. G., and Bhatti, N.: Sulfur dioxide emissions and sectorial contributions to sulfur deposition in Asia, Atmos. Environ., 31, 1553-1572, 1997.

Ayers, G. P., Keywood, M. D., Gillet, R. W., Manins, P. C., Malfroy, H., and Bardsley, T.: Validation of passive diffusion samplers for $\mathrm{SO}_{2}$ and $\mathrm{NO}_{2}$, Atmos. Environ., 32, 3593-3609, 1998.

Bakwin, P. S., Wofsy, S. C., and Fan, S.-M.: Measurements of reactive nitrogen oxides (NOy) within and above a tropical forest canopy in the wet season, J. Geophys. Res., 95, 16765-16772, 1990.

Balme, M., Vischel, T., Lebel, T., Peugoet, C., and Galle, S.: Assessing the water balance in the sahel : Impact of small scale rainfall variability on runoff, Part1: Rainfall variability analysis, J. Hydrol., 331(1-2), 336-348, 2006.

Barnett, D. and Davis, E. G.: A GC method for the determination of sulphur dioxide in food headspaces, J. Chrom. Sci., 21, 205-208, 1983.

Bates, T., Scholes, M., Doherty, S., and Young, B.: IGAC Science Plan and Implementation Strategy IGBP Report 56, IGBP Secretariat, Stockholm, Sweden, 44 pp., 2006.

Bates, T. S., Lamb, B. K., Guenther, A., Dignon, J., and Stoiber, R. E.: Sulfur emissions to the atmosphere from natural sources, J. Atmos. Chem., 14, 315-317, 1992.

Bouwman, A. F., Boumans, L. J. M., and Batjes, N. H.: Estimation of global $\mathrm{NH}_{3}$ volatilization loss from synthetic fertilizers and animal manure applied to arable lands and grasslands, Global Biogeochem. Cy., 16(2), 1024, doi:10.1029/2000GB001389, 2002a.

Brimblecombe, P., Hara, H., Houle, D., and Novak, M.: Acid Rain Deposition to Recovery, Springer edition, Reprinted from Water Air Soil Pollut.: Focus, 7(1-3), VIII, 420 pp., Hardcover, ISBN: 978-1-4020-5884-4, 2007.

Brocard, D., Galy-Lacaux, C., Lacaux, J. P., Kouadio, G., and Yoboué, V.: Emissions from the combustion of biofuels in western Africa, in: Global Biomass burning, edited by: Levine, J. S., MIT Press, Cambridge, Mass, 350-360, 1996.

Campos, V. P., Cruz, L. P. S, Godoi , R. H. M, Godoi, A. F. L., and Tavares, T. M.: Development and validation of passive samplers for atmospheric monitoring of $\mathrm{SO}_{2}, \mathrm{NO}_{2}, \mathrm{O}_{3}$ and $\mathrm{H}_{2} \mathrm{~S}$ in tropical areas, Microchem. J., 96(1), 132-138, 2010.

Carmichael, G. R., Ferm, M., Thongboonchoo, N., Woo, J.-H., Chan, L. Y., Murano, K., Viet, P. H., Mossberg, C., Bala, R., Boonjawat, J., Upatum, P., Mohan, M., Adhikary, S. P., Shrestha, A. B., Pienaar, J. J., Brunke, E. B., Chen, T., Jie, T., Guoan, D., Peng, L. C., Dhiharto, S., Harjanto, H., Jose, A. M., Kimani, W., Kirouane, A., Lacaux, J. P., Richard, S., Barturen, O., Cerda, J. C., Athayde, A., Tavares, T., Cotrina, J. S., and Bilici, E.: Measurements of sulfur dioxide, ozone and ammonia concentrations in Asia, Africa, and South America using passive samplers, Atmos. Environ., 37, 1293-1308, 2003.

Carmichael, G. R., Hong, M. S., Ueda, H., Chen, L. L., Murano, K., Kang, C., and Shim, S.: Aerosol composition at Cheju Island, Korea, J. Geophys. Res., 102, 6047-6061, 1997.

Carmichael, G. R., Zhang, Y., Chen, L. L., Hong, M. S., and Ueda, H.: Seasonal variation of aerosol composition at Cheju Island, Korea, Atmos. Environ., 30, 2407-2416, 1996.

Chestnut, L. G.: Human Health Benefits From Sulfate Reductions Under Title IV of the 1990 Clean Air Act Amendments, Final Report, US EPA, Office of Atmospheric Programs, Acid Rain
Division, 1995.

Cooke, W. F., Koffi, B., and Grégoire, J.-M.: Seasonality of vegetation fires in Africa from remote sensing data and application to a global chemistry model, J. Geophys. Res., 101, 21051-21065, 1996.

Cros, B., Delmas, R., Clairac, B., Loemba-Ndembi, J., and Fontan, J.: Survey of ozone concentrations in an equatorial region during the rainy season, J. Geophys. Res., 92, 9772-9778, 1987.

Cros, B., Delon, C., Affre, C., Marion, T., Druilhet, A., Perros, P. E., and Lopez, A.: Sources and sinks of ozone in savanna and forest areas during EXPRESSO: Airborne turbulent flux measurements, J. Geophys. Res., 105, 29347-29358, 2000.

Cros, B., Fontan, J., Minga, A., Helas, G., Nganga, D., Delmas, R., Chapuis, A., Benech, B., Druilhet, A., and Andreae, M. O.: Vertical profiles of ozones between 0 and 400 meters in and above the African equatorial Forest, J. Geophys. Res., 97, 12877-12887, 1992.

Cruz, L. P. S., Campos, V. P., Silva, A. M. C., and Tavares, T. M.: A field evaluation of a $\mathrm{SO}_{2}$ passive sampler in tropical industrial and urban air, Atmos. Environ., 38, 6425-6429, 2004.

Davidson, E. A.: Pulses of nitric oxide and nitrous oxide flux following wetting of dry soil: An assessment of probable sources and importance relative to annual fluxes, Ecol. Bull., 42, 149$155,1992$.

Debaje, S. B., Jeyakumar, S. J., Ganesan, K., Jadhav, D. B., and Seetaramayya, P.: Surface ozone measurements at tropical rural coastal station Tranquebar, India, Atmos. Environ., 37, 49114916, 2003.

Delmas, R. A., Lacaux, J. P., Menaut, J. C., Abbadie, L., Le Roux, X., Helas, G., and Lobert, G.: Nitrogen compound emission from biomass burning in tropical African savanna, FOS/DECAFE 91 Experiment (Lamto, Cote d'Ivoire), J. Atmos. Chem., 22, 175194, 1995.

Delon, C., Reeves, C. E., Stewart, D. J., Serça, D., Dupont, R., Mari, C., Chaboureau, J.-P., and Tulet, P.: Biogenic nitrogen oxide emissions from soils - impact on $\mathrm{NO}_{\mathrm{x}}$ and ozone over West Africa during AMMA (African Monsoon Multidisciplinary Experiment): modelling study, Atmos. Chem. Phys., 8, 2351-2363, doi:10.5194/acp-8-2351-2008, 2008.

Delon, C., Galy-Lacaux, C., Boone, A., Liousse, C., Serça, D., Adon, M., Diop, B., Akpo, A., Lavenu, F., Mougin, E., and Timouk, F.: Atmospheric nitrogen budget in Sahelian dry savannas, Atmos. Chem. Phys., 10, 2691-2708, doi:10.5194/acp-10-26912010, 2010.

Dentener, F. J., Carmichael, G. R., Zhang, Y., Lelieveld, Y. J., and Crutzen, P. J.: Role of mineral aerosols as a reactive surface in the global troposphere, J. Geophys. Res., 101, 22869-22889, 1996.

Dhammapala, R.: Use of passive samplers for the sampling of Atmospheric pollutants, M. Sc. Thesis, Potchefstroom University for CHE, South Africa, 1996.

EU: Council Directive 1999/30/EC relating to limit values for sulfur dioxide, nitrogen dioxide and oxides of nitrogen, particulate matter and lead in ambient air, Official Journal of European communities L163/41, 1999.

Ferm, M. and Rodhe, H.: Measurements of air concentrations of $\mathrm{SO}_{2}, \mathrm{NO}_{2}$ and $\mathrm{NH}_{3}$ at rural and remote sites in Asia, J. Atmos. Chem., 27, 17-29, 1997.

Ferm, M. and Svanberg, P.-A.: Cost-effective techniques for urban and background measurements of $\mathrm{SO}_{2}$ and $\mathrm{NO}_{2}$, Atmos. Envi- 
ron., 32, 1377-1381, 1998.

Ferm, M., De Santis, F., and Varotsos, C.: Nitric acid measurements in connection with corrosion studies, Atmos. Environ., 39, 66646672,2005

Ferm, M., Lindskog, A., Svanberg, P.-A., and Boström, C.-A.: New measurement technique for air pollutants (in Swedish), Kemisk Tidskrift, 1, 30-32, 1994.

Ferm, M.: A sensitive Diffusional Sampler. IVL publication B 1020, Swedish Environmental Research Institute, Box 47086, 40258 Gotebory, Sweden, 1-12, 1991.

Ferm, M.: The theories behind diffusive sampling. Proceedings from the International Conference on Measuring Air Pollutants by Diffusive Sampling, Montpellier, France, 26-28 September 2001, 31-40, 2001.

Galanter, M., Levy II, H., and Carmichael, G. R.: Impacts of biomass burning on tropospheric $\mathrm{CO}, \mathrm{NO}_{\mathrm{x}}$, and $\mathrm{O}_{3}$, J. Geophys. Res., 105, 6633-6653, 2000.

Galy-Lacaux, C. and Modi, A. I.: Precipitation chemistry in the Sahelian Savanna of Niger, Africa, J. Atmos. Chem., 30, 319334, 1998.

Galy-Lacaux, C., Carmichael, G. R., Song, C. H., Lacaux, J. P., and Modi, I.: Heterogenous processes involving nitrogenous compounds and Saharan dust inferred from measurements and model calculations Region, J. Geophys. Res., 106, 12559-12578, 2001.

Galy-Lacaux, C., Laouali, D., Descroix, L., Gobron, N., and Liousse, C.: Long term precipitation chemistry and wet deposition in a remote dry savanna site in Africa (Niger), Atmos. Chem. Phys., 9, 1579-1595, doi:10.5194/acp-9-1579-2009, 2009.

Garland, J. A.: The dry deposition of sulphur dioxide to land and water surfaces, Proceedings Royal Society London, A 354, 245 268, 1977.

Gautier, L.: Contact forêt-savane en Côte d'Ivoire centrale : évolution de la surface forestière de la réserve de Lamto (sud de V-Baoulé), Candoella, 45, 627-641, 1990.

Graedel, T. E. and Crutzen, P. J.: Atmospheric change: An Earth System Perspective, W. H. Freeman and Company, New York, 446 pp., 1993.

Gupta, A., Kumar, R., Kumari, K. M., and Srivastava, S. S.: Measurement of $\mathrm{NO}_{2}, \mathrm{HNO}_{3}, \mathrm{NH}_{3}$ and $\mathrm{SO}_{2}$ and related particulate matter at a rural site in Rampur, India, Atmos. Environ., 37, 4837-4846, 2003.

Hansen, J., Sato, M., Nazarenko, L., Ruedy, R., Lacis, A., Koch, D., Tegen, I., Hall, T., Shindell, D., Santer, B., Stone, P., Novakov, T., Thomason, L., Wang, R., Wang, Y., Jacob, D., Hollandsworth, S., Bishop, L., Logan, J., Thompson, A., Stolarski, R., Lean, J., Willson, R., Levitus, S., Antonov, J., Rayner, N., Parker, D., and Christy, J.: Climate forcings in Goddard Institute for Space Studies SI2000 simulations, J. Geophys. Res., 107, 4347, doi:10.1029/2001JD001143, 2002.

Hao, W. M. and Liu, M.-H.: Spatial and temporal distribution of tropical biomass burning, Global Biogeochem. Cy., 8, 495-503, 1994.

Jacob, D. J. and Bakwin, P. S.: Cycling of $\mathrm{NO}_{\mathrm{x}}$ in tropical forest canopies, in: Microbial Production and Consumption of Greenhouse Gases: Methane, Nitrogen Oxides, and Halomethane, edited by: Rogers, J. E. and Whitman, W. B., chap. 13, Am. Soc. Microbiol., Washington, DC, 237-253, 1991.

Jacob, D. J. and Wofsy, S. C.: Budgets of reactive nitrogen, hydrocarbons, and ozone over the Amazon-Forest during the wet season, J. Geophys. Res., 95, 16737-16754, 1990.

Jacob, D. J., Heikes, B. G., Dickerson, R. R., Artz, R. S., and Keene, W. C.: Evidence for a seasonal transition from $\mathrm{NO}_{\mathrm{X}}-$ to hydrocarbon-limited ozone production at Shenandoah National Park, Virginia, J. Geophys. Res., 100, 9315-9324, 1995.

Jaegle, L., Martin, R. V., Chance, K., Steinberger, L., Kurosu,T. P., Jacob, D. J., Modi, A. I., Yoboué, V., Sigha-Nkamdjou, L., and Galy-Lacaux, C.: Satellite mapping of rain-induced nitric oxide emissions from soils, J. Geophys. Res., 109, D21310, doi:10.1029/2004JD004787, 2004.

Jaegle, L., Steinberger, L., Martin, R. V., and Chance, K.: Global partitioning of $\mathrm{NO}_{\mathrm{x}}$ sources using satellite observations: Relative roles of fossil fuel combustion, biomass burning and soil emissions, Faraday Discuss., 130, 407-423 doi:10.1039/b502128f, 2005.

Johansson, C. and Sanhueza, E.: Emissions of NO from savannah soils during rainy season, J. Geophys. Res., 93, 14193-14198, 1988.

Josipovic, M., Annegarn, H., Kneen, M., Piketh, S., and Pienaar J.: A regional passive monitoring Study of $\mathrm{SO}_{2}, \mathrm{NO}_{2}$ and Ozone in South Africa, IGACtivities Newsletter no. 36, July 2007.

Kaplan, W. A., Wofsy, S. C., Keller, M., and Da Costa, J. M.: Emission of $\mathrm{NO}$ and deposition of $\mathrm{O}_{3}$ in a tropical forest system, J. Geophys. Res., 93, 1389-1395, 1988.

Koutrakis, P., Wolfson, J. M., Bunyaviroch, A., Froehlich, S. E., Hirano, K., and Mulik, J. D.: Measurement of ambient ozone using a nitrite coated filter, Anal. Chem., 65, 209-214, 1993.

Lacaux, J. P., Brustet, J. M., Delmas, R., Menaut, J. C., Abbadie, L., Bonsang, B., Cachier, H., Baudet, J. G. R., Andreae, M. O., and Helas, G.: Biomass burning in the tropical savannas of Cote d'Ivoire: An overview of the field experiment Fire of Savannas (FOS/DECAFE 91), J. Atmos. Chem., 22, 195-216, 1995.

Lacaux, J. P., Tathy, J. P., and Sigha, L.: Acid wet deposition in the tropics: two case studies using DEBITS measurements, IGACtivities Newsletter of the International Global Atmospheric Chemistry Project, DEBITS Special 2, 13-18, 2003.

Laville, P., Hénault, C., Gabrielle, B., and Serça, D.: Measurement and modelling of NO fluxes over maize and wheat crops during their growing seasons: effect of crop management, Nutr. Cycl. Agroecosyst. 72, 159-171, 2005.

Lebel T., Parker, D. J., Bourles, B., Diedhiou, A., Gaye, A., Polcher, J., Redelsperger, J.-L., and Thorncroft, C. D.: AMMA field campaigns in 2005 and 2006, Gewex News, 1, 4-6, 2007.

Liu, S. C., Trainer, M., Fehsenfeld, F. C., Parrish, D. D., Williams, E. J., Fahey, D. W., Hubler, G., and Murphy, P. C.: Ozone production in the rural troposphere and the implications for regional and global ozone distributions, J. Geophys. Res., 92, 4191-4207, 1987.

Lobert, J. M., Scharffe, D. H., Hao, W. M., and Crutzen, P. J.: Importance of biomass burning in the atmospheric budgets of nitrogen containing gases, Nature, 346, 552-524, 1990.

Ludwig, J., Meixner, F. X., Vogel, B., and Forstner, J.: Soil-air exchange of nitric oxide: An overview of processes, environmental factors, and modelling studies, Biogeochemistry, 52, 225-257, 2001.

Macdonalda, B. C. T., Denmeadb, O. T., Ian Whitea, I., Michael, D., and Melvillec, M. D.: Natural sulfur dioxide emissions from sulfuric soils, Atmos. Environ., 38, 1473-1480, 2004.

Martins, J. J., Dhammapala, R. S., Lachmann, G., Galy-Lacaux, 
C., and Pienaar, J. J.: Long-term measurements of sulphur dioxide, nitrogen dioxide, ammonia, nitric acid and ozone in southern Africa using passive samplers, S. Afr. J. Sci., 103(7-8), 336-342, 2007.

Mauzerall, D. L. and Wang, X. P.: Protecting agricultural crops from the effects of tropospheric ozone exposure: Reconciling science and standard setting in the United States, Europe, and Asia, Ann. Rev. Energy Environ., 26, 237-268, 2001.

McCalley, C. K. and Sparks, J. P.: Controls over nitric oxide and ammonia emissions from Mojave Desert soils, Oecologia, 156, 871-881, 2008.

Mc Granaham, G. and Murray, F.: air pollution and health in rapidly developing countries, edition SEI Earthscan, 1-227, ISBN 185383-985-X, 2003.

Menaut, J. C., Abbadie, L., Levanu, F., Loudjani, P., and Podaire, A.: Biomass burning in West African Savannas, in: Global Biomass Burning: Atmospheric, Climatic, and Biospheric Implications, edited by: Levine, J. S., MIT Press, Cambridge, Mass, 133-142, 1991.

Mphepya, J. N., Galy-Lacaux, C., Lacaux, J. P., Held, G., and Pienaar, J. J.: Precipitation Chemistry and Wet Deposition in Kruger National Park, South Africa, J. Atmos. Chem., 53, 169-183, 2006.

Mphepya, J. N., Pienaar, J. J., Galy-Lacaux, C., Held, G., and Turner, C. R.: Precipitation Chemistry in Semi-Arid Areas of Southern Africa: A Case Study of a Rural and an industrial Site, J. Atmos. Chem., 47, 1-24, 2004.

Modi, A. I., Lacaux, J. P., Labroue, L., and Baudet, J. G. R.: Chimie des aérosols et des pluies dans la savane semi-aride du Niger pendant la saison humide 1989, Sécheresse, 6, 331-335, 1995.

Mougin, E., Hiernaux, P., Kergoat, L., Grippa, M., De Rosnay, P., Timouk, F., Le Dantec, V., Demarez, V., Arjounin, M., Lavenu, F., Soumaguel, N., Ceschia, E., Mougenot, B., Baup, F., Frappart, F., Frison, P. L., Gardelle, J., Gruhier, C., Jarlan, L., Mangiarotti, S., Sanou, B., Tracol, Y., Guichard, F., Trichon, V., Diarra, L., Soumaré, A., Koité, M., Dembélé, F., Lloyd, C., Hanan, N. P., Damesin, C., Delon, C., Serça, D., Galy-Lacaux, C., Seghiéri, J., Becerra, S., Dia, H., Gangneron, F., and Mazzega, P.: The AMMA-CATCH Gourma observatory site in Mali: Relating climatic variations to changes in vegetation, surface hydrology, fluxes and natural resources, J. Hydrol., AMMA-CATCH Special issue, 375, 14-33, doi:10.1016/j.jhydrol.2009.06.045, 2009.

National Research Council (NRC): Committee on Tropospheric Ozone Formation and Measurement. Rethinking the Ozone Problem in Urban and Regional Air Pollution, National Academy Press, Washington, 1991.

Naja, M. and Lal, S.: Surface ozone and precursor gases at Gadanki $\left(13.5^{\circ} \mathrm{N}, 79.2^{\circ} \mathrm{E}\right)$, a tropical rural site in India, J. Geophys. Res., 107, 4197, doi:10.1029/2001JD000357, 2002.

Pienaar, J. J.: Proposal of a new IGAC II task: DEBITS II (Deposition of Biogeochemically Important Trace Species), available at: http://www.igac.noaa.gov/DEBITS.php, 2005.

Rondon, A. and Sanhueza, E.: Seasonal variation of gaseous $\mathrm{HNO}_{3}$ and $\mathrm{NH}_{3}$ at a tropical savannah site, J. Atmos. Chem., 11(3), 245-254, 1990.

Rummel, U., Ammann, C., Kirkman, G. A., Moura, M. A. L., Foken, T., Andreae, M. O., and Meixner, F. X.: Seasonal variation of ozone deposition to a tropical rain forest in southwest Amazonia, Atmos. Chem. Phys., 7, 5415-5435, doi:10.5194/acp-7-
5415-2007, 2007.

Saunois, M., Reeves, C. E., Mari, C. H., Murphy, J. G., Stewart, D. J., Mills, G. P., Oram, D. E., and Purvis, R. M.: Factors controlling the distribution of ozone in the West African lower troposphere during the AMMA (African Monsoon Multidisciplinary Analysis) wet season campaign, Atmos. Chem. Phys., 9, 61356155, doi:10.5194/acp-9-6135-2009, 2009.

Schlecht, E., Fernandez-Rivera, S., and Hiernaux, P.: Timing, size and $\mathrm{N}$-concentration of faecal and urinary excretions in cattle, sheep and goats - can they be used for better manuring of cropland? in: Soil fertility Management in West AfricanLand Use Systems, edited by: Renard, G., Neef, A., Becker, K., and von Oppen, M., Margraf Verlag, Weikersheim, Germany, 361-368, 1998.

Schlesinger, W. H. and Hartley, A. E.: A global budget for $\mathrm{NH}_{3}$, Biogeochemistry, 15, 191-211, 1992.

Scholes, M., Martin, R., Scholes, R. J., Parsons, D., and Winstead, E.: $\mathrm{NO}$ and $\mathrm{N}_{2} \mathrm{O}$ emissions from savanna soils following the first simulated rains of the season, Nutr. Cycl. Agroecosys. 48, 115122, 1997.

Serça, D., Delmas, R., Le Roux, X., Parsons, D. A. B., Scholes, M. C., Abbadie, L., Lensi, R., Ronce, O., and Labroue, L. : Comparison of nitrogen monoxide emissions from several African tropical ecosystems and influence of season and fire, Global Biogeochem. Cy., 12, 637-651, 1998.

Sigha-Nkamdjou, L., Galy-Lacaux, C., Pont, V., Richard, S., Sighoumnou, D., and Lacaux, J. P.: Rainwater chemistry and wet deposition over the equatorial forested ecosystem of Zoétélé (Cameroon), J. Atmos. Chem., 46, 173-198, 2003.

Smith, S. J., Pitcher, H., and Wigley, T. M. L.: Global and regional anthropogenic sulfur dioxide emissions, Global Planet. Change, 29, 99-119, 2001.

Sparks, J. P., Monson, R. K., Sparks, K. L., and Lerdau, M.: Leaf uptake of nitrogen dioxide $\left(\mathrm{NO}_{2}\right)$ in a tropical wet forest: implication for tropospheric chemistry, Oecologia 127, 214-221, 2001.

Stevenson, K., Bush, T., and Mooney, D.: Five years of nitrogen dioxide measurement with diffusion tube samplers at over 1000 sites in the UK, Atmos. Environ., 35, 281-287, 2001.

Stewart, D. J., Taylor, C. M., Reeves, C. E., and McQuaid, J. B.: Biogenic nitrogen oxide emissions from soils: impact on $\mathrm{NO}_{\mathrm{x}}$ and ozone over west Africa during AMMA (African Monsoon Multidisciplinary Analysis): observational study, Atmos. Chem. Phys., 8, 2285-2297, doi:10.5194/acp-8-2285-2008, 2008.

Sutton, M., Reis, S., and Baker, S. M. H.: Atmospheric Ammonia, detecting emission changes and environmental impacts. Results of an expert workshop under the convention of long range transboundary air pollution, Springer Edition, New York, ISBN 978-1-4020-9120-9, 2009.

Tidblad, J., Kucera, V., Samie, F., Das, S. N., Bhamornsut, C., Peng, L. P., Lung So, K., Dawei, Z., Hong Lien, L. T., Schollenberger, H., Lungu, C. V., and Simbi, D.: Exposure Programme on Atmospheric Corrosion Effects of Acidifying Pollutants in Tropical and Subtropical Climates, Water Air Soil Pollut., 7, 241-247, 2007.

Trebs, I., Lara, L. L., Zeri, L. M. M., Gatti, L. V., Artaxo, P., Dlugi, R., Slanina, J., Andreae, M. O., and Meixner, F. X.: Dry and wet deposition of inorganic nitrogen compounds to a tropical pasture site (Rondônia, Brazil), Atmos. Chem. Phys., 6, 447-469, 
doi:10.5194/acp-6-447-2006, 2006.

Trebs, I., Meixner, F. X., Slanina, J., Otjes, R., Jongejan, P., and Andreae, M. O.: Real-time measurements of ammonia, acidic trace gases and water-soluble inorganic aerosol species at a rural site in the Amazon Basin, Atmos. Chem. Phys., 4, 967-987, doi:10.5194/acp-4-967-2004, 2004.

Van Breemen, N.: Acid Sulfate Weathering, Soil Science Society of America, Madison, Wisconsin, USA, 95-108, 1982.

Van Breemen, N.: Selected Papers of the Ho Chi Minh City Symposium on Acid Sulphate Soils, ILRI Pub No. 53, ILRI, Wageningen, The Netherlands, 391-401, 1993.

Williams, E. J., Guenther, A., and Fehsenfeld, F. C.: An inventory of nitric oxide emissions from soils in the United States, J. Geophys. Res., 97, 7511-7519, 1992.
WMO TD No. 829: Report on passive samplers for atmospheric chemistry measurements and their role in GAW (prepared by Carmichael),20 pp., 1997.

Yienger, J. J. and Levy II. H.: Empirical model of global soil biogenic $\mathrm{NO}_{\mathrm{x}}$ emissions, J. Geophys. Res., 100, 1447-1464, 1995.

Yoboue, V., Galy-Lacaux, C., Lacaux, J. P., and Silue, S. : Rainwater Chemistry and Wet Deposition over the Wet Savanna Ecosystem of Lamto (Cote d'Ivoire), J. Atmos. Chem., 52, 117-141, 2005.

Zhang, L., Brook, J. R., and Vet, R.: A revised parameterization for gaseous dry deposition in air-quality models, Atmos. Chem. Phys., 3, 2067-2082, doi:10.5194/acp-3-2067-2003, 2003.

Zunckel, M., Venjonoka, K., Pienaar, J. J., Brunke, E.-G., Pretorius, O., Koosailee, A., Raghunandan, A., and van Tienhoven, M. A.: Surface ozone over southern Africa: synthesis of monitoring results during the Cross Border Air Pollution Impact Assessment project, Atmos. Environ., 38, 6139-6147, 2004. 